\title{
6. MINERAL PARAGENESIS OF ALTERED BASALTS FROM HOLE 504B, ODP LEG 111
}

\author{
Hideo Ishizuka²
}

\begin{abstract}
Basalts recovered from Hole 504B during ODP Leg 111 are more or less altered, but there is no sign of strong shear stress or widespread penetrative deformation; hence, they retain well their primary (igneous) structures and textures. The effect of alteration is recognized as the partial or total replacement of primary minerals (olivine, clinopyroxene, and plagioclase) by secondary minerals and as the development of secondary minerals in open spaces (e.g., veins, fractures, vugs, or breccia matrix). The secondary minerals include zeolite (laumontite and stilbite), prehnite, chlorite, epidote, plagioclase (albite and/or oligoclase), amphibole (anthophyllite, cummingtonite, actinolite, and hornblende), sodic augite, sphene, talc, anhydrite, chalcopyrite, pyrite, Fe-Ti oxide, and quartz. Selected secondary minerals from several tens of samples were analyzed by means of an electron-probe microanalyzer; the results are presented along with brief considerations of their compositional features.

In terms of the model basaltic system, the following two types of low-variance (three-phase) mineral assemblages were observed: prehnite-epidote-laumontite and prehnite-actinolite-epidote; both include chlorite, albite and/or oligoclase, sphene, and quartz. The mineral parageneses delineated by these low-variance mineral assemblages suggest that the metamorphic grade ranges from the zeolite facies to the prehnite-actinolite facies. The common occurrence of prehnite indicates that greenschist facies conditions were not attained even in the deepest level of Hole 504B, which, in a strict sense, contradicts the previous interpretation that the lower portion of Hole 504B suffered greenschist facies alteration.
\end{abstract}

\section{INTRODUCTION}

Since Matthews et al. (1965) reported metamorphosed basalts dredged on the crest of the Carlsberg Ridge, the mid-ocean ridge in the northwestern Indian Ocean, occurrences of metamorphic rocks have been increasingly recognized from the ocean floor around the world. Particularly, petrologic studies of metamorphic rocks obtained from the ocean floor have thrown new light on the metamorphic processes taking place near divergent plate boundaries (Melson and van Andel, 1966; Cann and Funnell, 1967; Cann, 1969; Ploshko et al., 1970; Miyashiro et al., 1971; Aumento et al., 1971; Bonatti et al., 1975; Helmstaedt, 1977; Ito and Anderson, 1983; Honnorez et al., 1984; Alt et al., 1986). Miyashiro et al. (1971) called it "ocean-floor metamorphism." However, the majority of these studies dealt with dredged samples, for which the detailed metamorphic sequence of oceanic crust is not well known. Drilled samples are more suitable for understanding the sequential nature of ocean-floor metamorphism, because they represent a relatively continuous section of oceanic crust.

Hole 504B, located in 5.9-Ma-old oceanic crust at $3460 \mathrm{~m}$ below sea level about $200 \mathrm{~km}$ south of the Costa Rica Rift, was cored and logged during parts of Legs 69, 70, 83, and 92 of the Deep Sea Drilling Project (DSDP). Coring during these legs to $1350 \mathrm{~m}$ below seafloor (mbsf) (1075.5 m into basement) consisted of $274.5 \mathrm{~m}$ of sediment and then $571.5 \mathrm{~m}$ of pillow lavas and minor flows, underlain by a 209 -m-thick zone of transition into $295 \mathrm{~m}$ of sheeted dikes and massive units. Leg 111 of the Ocean Drilling Program (ODP) further deepened Hole 504B by $212.3 \mathrm{~m}$, to a total depth of 1562.3 mbsf (1287.8 $\mathrm{m}$ into basement). Hole 504B thus provides an excellent opportunity for understanding the nature of metamorphism of the oceanic crust.

\footnotetext{
${ }^{1}$ Becker, K., Sakai, H., et al., 1989. Proc. ODP, Sci. Results, 111: College Station, TX (Ocean Drilling Program).

2 Department of Geology, Kochi University, Kochi 780, Japan.
}

The following is a petrological description of the basalts recovered from Hole 504B during ODP Leg 111, along with a discussion of their mineral parageneses.

\section{PETROGRAPHY}

\section{Precursor Basalts}

The basalts recovered from Hole 504B during ODP Leg 111 represent a 212.3-m section of the oceanic crust ranging in depth from 1350 to $1562.3 \mathrm{mbsf}$, or from 1075.5 to $1287.8 \mathrm{~m}$ into basement. Chilled intrusive contacts are distinct in several portions of the cores, suggesting that the basalts are all from massive dike units. At or near the chilled intrusive contacts, there are breccias (so-called chilled marginal breccias) composed of angular and glassy fragments cemented in a fine-grained basaltic matrix. The basalts are more or less altered, but they lack evidence of strong shear stress or widespread penetrative deformation. Hence, their primary (igneous) structures as well as textures can be recognized, and the first classification of rock type is into aphyric and phyric basalts, of which the former comprises one-third of the examined samples. There is no sign of vesiculation, although irregular millimeter-sized vugs are present both in the aphyric and phyric basalts.

The aphyric basalts include essentially no phenocrysts; for practical purposes they contain less than $1 \%$ phenocrysts. They are fine to medium in grain size and are composed of olivine, clinopyroxene, and plagioclase with minor Fe-Ti oxide. Subophitic texture dominates the medium-grained aphyric rocks, but the fine-grained varieties exhibit intergranular texture. In contrast, the phyric basalts have a texture in which more than $1 \%$ phenocrysts are set within a crystalline or glassy groundmass. They are composed of olivine, clinopyroxene, plagioclase, $\mathrm{Cr}$ spinel, and Fe-Ti oxide, of which the $\mathrm{Cr}$-spinel is found as inclusions in olivine and/or plagioclase phenocrysts whereas the other phases comprise both phenocrysts and groundmass with various combinations. The groundmass of the phyric basalts ranges in grain size from glassy to medium grained and displays subophitic to intergranular texture. 


\section{Alteration}

Alteration was described in the present study from 48 thin sections. The primary and secondary minerals found in the thin sections are listed in Table 1.

Both the aphyric and phyric basalts examined here are generally moderately altered (about $10 \%-30 \%$ recrystallized). The degree of alteration appears to be higher in fine-grained rocks than in medium-grained ones, although the glassy materials are generally less altered. The effect of alteration is recognized as partial or total replacement of primary (igneous) phases by secondary minerals and as development of secondary minerals in open spaces (e.g., veins, fractures, vugs, or breccia matrix), which is summarized in the following.

\section{Olivine}

Dark green to dark brown pseudomorphs after olivine phenocrysts as well as groundmass olivine are well recognized by a characteristic olivine crystal form, and some pseudomorphs after olivine phenocrysts include a tiny euhedral and unaltered $\mathrm{Cr}$ spinel (Fig. 1A). Secondary minerals found in olivine pseudomorphs are amphibole, chlorite with or without mixed-layer clay, talc, quartz, sulfides (pyrite and chalcopyrite), and secondary magnetite. Locally (e.g., Sample 111-504B-142R-1, 2-4 cm) olivine retains its primary composition, but its margin and irregular cracks are altered to talc and chlorite.

\section{Clinopyroxene}

Among the constituent primary minerals, clinopyroxene is the least altered mineral. Secondary minerals are restricted to the margin around or cracks within clinopyroxene phenocrysts (Fig. 1B), whereas some of the groundmass clinopyroxene is totally altered. Chlorite and/or amphibole are the most common secondary minerals replacing clinopyroxene both in phenocrysts and groundmass.

\section{Plagioclase}

In both phenocrysts and groundmass, plagioclase is partially altered to sodium-rich plagioclase (albite and/or oligoclase), prehnite, zeolite, and chlorite. In Sample 111-504B-142R-1, 118-121 $\mathrm{cm}$, a single phenocryst of plagioclase is totally replaced both by prehnite and zeolite (stilbite) (Fig. 1C). Anhydrite was rarely found partly replacing plagioclase phenocrysts (Fig. 1D). Glass inclusions, some of which are aligned parallel to twin planes of large plagioclase phenocrysts, are generally altered to chlorite and/or mixed-layer clay.

\section{Veins, Fractures, Vugs, and Breccia Matrix}

Besides the secondary minerals associated with the primary phases previously described, veins or fractures or vugs that commonly occur in varying abundance both in the aphyric and phyric basalts also include various kinds of secondary minerals such as prehnite, chlorite, amphibole, epidote, and zeolite. All of these secondary minerals do not coexist. Monomineralic (generally chlorite) veins or fractures are also abundant. The mineral associations observed in the veins or fractures or vugs including more than two phases are as follows: prehnite, prehnite + amphibole (Fig. 2A), prehnite + amphibole + epidote (Fig. 2B), prehnite + epidote + zeolite (Fig. 2C), and prehnite + amphibole + zeolite, all including chlorite, sphene, and Fe$\mathrm{Ti}$ oxide with or without albite and/or oligoclase and quartz. Of these, the amphibole-zeolite association has the textural relationship showing that the amphibole develops as needlelike crystals scattered within the zeolite grain. This may represent a disequilibrium relationship between amphibole and zeolite. Sodic augite-bearing veins also occur together with chlorite, zeolite, and prehnite (Fig. 2D). The breccia matrix is extremely al- tered $(50 \%-100 \%$ recrystallized) to amphibole, chlorite, prehnite, zeolite, and albite with disseminated sphene, in which the amphibole and zeolite also show the same textural relationship as previously described. Locally (e.g., Sample 111-504B-159R$1,52-56 \mathrm{~cm}$ ) a completely altered patch, ranging from $0.5 \mathrm{~mm}$ to $1.0 \mathrm{~cm}$ in diameter, occurs both in aphyric and phyric basalts, in which clinopyroxene is completely altered to needlelike to prismatic amphibole with minor chlorite.

\section{MINERALOGY OF SECONDARY MINERALS}

Before dealing with the mineral paragenesis, the chemistry and mode of occurrence of selected secondary minerals are described in this section. The analyses were performed using a JEOL Model JXA-733 electron-probe microanalyzer with a wavelength-dispersive analytical system (WDS) at the National Institute of Polar Research (Tokyo). Supplementary microprobe analyses were done using a Hitachi Model S-550 scanning electron microscope with a Kevex energy-dispersive analytical system (EDS), at Kyoto University, and a JEOL Model JXA-733 with WDS, at the Ocean Research Institute (University of Tokyo).

In total, 32 polished thin sections were analyzed, and the mineral assemblages are given in Table 1. The chemical nature of selected secondary minerals is summarized in Table 2, and representative analyses are listed in Tables 3 to 9 .

\section{Zeolites}

Analyzed zeolites (Table 3) are identified as laumontite and stilbite. The laumontite is commonly found as discrete patches in veins, fractures, vugs, and breccia matrix, and some occurs as partially replacing primary plagioclase. The stilbite is generally restricted to a partial replacement of primary plagioclase, but in Sample 111-504B-149R-2, 50-53 cm, it fills a vein as platy crystals. There is, however, no association of laumontite + stilbite (1) in a single vein or fracture or vug or (2) in a replacement of a single primary plagioclase crystal.

Compositionally, the zeolites are commonly homogeneous, approaching the ideal stoichiometry of laumontite and stilbite, respectively, even though some small amounts of $\mathrm{Na}_{2} \mathrm{O}$ are contained in laumontite (up to $0.66 \mathrm{wt} \%$ ) and stilbite (up to 0.29 wt $\%$ ).

\section{Prehnite}

Prehnite (Table 4) occurs mainly as discrete patches in veins, fractures, vugs, and breccia matrix or as fine-grained aggregates after plagioclase phenocrysts. Some anhedral platy prehnite appears as homogeneous crystal aggregates in veins. Rarely, prehnite with rotatory extinction between crossed nicols is found partially replacing primary plagioclase.

The frequency distribution of $\mathrm{XFe}=\mathrm{Fe}^{3+} /\left(\mathrm{Fe}^{3+}+\mathrm{Al}\right)$ of prehnite is illustrated in Figure 3. Compositionally, besides the major oxides $\left(\mathrm{SiO}_{2}, \mathrm{Al}_{2} \mathrm{O}_{3}\right.$, and $\left.\mathrm{CaO}\right)$, the prehnites contain a significant amount of $\mathrm{Fe}_{2} \mathrm{O}_{3}{ }^{*}$, up to $7.9 \mathrm{wt} \%$. The XFe content was found to be apparently higher in prehnite associated with laumontite + epidote than in that with actinolite + epidote.

\section{Chlorite}

Chlorite (Table 5) is the most common secondary mineral, occurring in veins, fractures, vugs, and breccia matrix. Chlorite also occurs as partially to totally replacing primary olivine, clinopyroxene, and plagioclase; it commonly takes the form of fine-grained aggregates, but some shows an anhedral platy form.

The compositional variation of chlorite in terms of $\mathrm{Al}-\mathrm{Fe}-$ $\mathrm{Mg}$ is illustrated in Figure 4. There is a slight compositional difference in relation to mode of occurrence; for example, the most magnesian chlorite occurs within olivine pseudomorphs whereas the most aluminous one occurs along the cracks of plagioclase phenocrysts. In spite of this slight compositional difference, the 
Table 1. Mineral associations, Hole 504B, ODP Leg 111.

\begin{tabular}{|c|c|c|c|c|c|c|c|c|c|c|c|c|c|c|}
\hline $\begin{array}{l}\text { Core, section, } \\
\text { interval }(\mathrm{cm})\end{array}$ & $\begin{array}{l}\text { Depth } \\
\text { (mbsf) }\end{array}$ & $\begin{array}{c}\text { Primary } \\
\text { clino- } \\
\text { pyroxene }\end{array}$ & $\begin{array}{c}\text { Primary } \\
\text { plagioclase }\end{array}$ & $\begin{array}{c}\text { Primary } \\
\text { spinel }\end{array}$ & $\begin{array}{c}\text { Olivine } \\
\text { pseudo- } \\
\text { morph }\end{array}$ & Amphibole & Epidote & Chlorite & Prehnite & Zeolite & $\begin{array}{c}\text { Meta- } \\
\text { morphic } \\
\text { plagioclase }\end{array}$ & Quartz & Sphene & $\begin{array}{l}\text { Anhydrite/ } \\
\text { metamorphic } \\
\text { clinopyroxene } \\
\text { (sodic augite) }\end{array}$ \\
\hline$b_{142 R-1,2-4}$ & 1352.8 & + & + & + & + & + & & + & & & & & + & \\
\hline $142 \mathrm{R}-1,2-4$ & 1352.8 & + & + & & + & & & + & & & & & & \\
\hline${ }^{b} 142 R-1,118-121$ & 1354.0 & + & + & & + & + & + & + & + & + & + & + & + & \\
\hline$b_{142 R-2,73-75}$ & 1355.0 & + & + & & + & + & & + & & & + & + & & \\
\hline $142 \mathrm{R}-2,73-75$ & 1355.0 & + & + & & + & + & & + & & & + & + & & \\
\hline $143 \mathrm{R}-1,33-35$ & 1359.6 & + & + & + & + & & + & & & & & & & \\
\hline$b_{143 \mathrm{R}-1,108-112}$ & 1360.4 & + & + & + & + & + & & + & & & & + & & \\
\hline $144 \mathrm{R}-1,0-2$ & 1368.7 & + & + & & + & + & & + & & & & & + & \\
\hline b $144 R-1,43-47$ & 1369.1 & + & + & + & + & + & & + & & & & & & \\
\hline $144 \mathrm{R}-1,86-88$ & 1369.6 & + & + & + & + & & & + & & & & & & \\
\hline $144 \mathrm{R}-1,110-111$ & 1369.8 & + & + & & + & & & + & & & & & & \\
\hline$b_{145 R-3,137-138}$ & 1384.2 & + & + & & + & + & & + & & & & + & + & \\
\hline $145 \mathrm{R}-4,20-22$ & 1384.5 & + & + & & + & & & + & & & + & + & + & \\
\hline $146 \mathrm{R}-1,7-9$ & 1388.1 & + & + & & + & + & & + & & & + & & + & \\
\hline $147 \mathrm{R}-2,30-33$ & 1399.2 & + & + & & + & + & & + & & + & & & + & \\
\hline $149 \mathrm{R}-2,12-15$ & 1418.5 & + & + & & + & & & + & & & & & & \\
\hline $149 \mathrm{R}-2,50-53$ & 1418.9 & + & + & & + & + & & + & + & + & + & + & + & \\
\hline$b_{149 R-2,} 57-59$ & 1419.0 & + & + & & + & + & & + & & + & + & & + & \\
\hline $150 \mathrm{R}-1,54-56$ & 1426.9 & + & + & & + & & & + & & & + & & & \\
\hline $150 \mathrm{R}-1,54-56$ & 1426.9 & + & + & & + & + & & + & & & & & + & \\
\hline$b_{150 R-1,81-83}$ & 1427.2 & + & + & & + & + & & + & & & & & + & \\
\hline $151 \mathrm{R}-1,33-35$ & 1431.1 & + & + & & + & + & & + & + & & + & & + & \\
\hline$b_{152 R-1,5-8}$ & 1436.0 & + & + & & & + & & + & + & & + & & + & \\
\hline$b_{152 R-1,17-19}$ & 1436.1 & & + & & & + & & + & + & + & + & & + & Ah \\
\hline b $152 \mathrm{R}-1,61-64$ & 1436.5 & + & + & & + & + & & + & + & + & + & & & $\mathrm{Ah} / \mathrm{Mp}$ \\
\hline $152 \mathrm{R}-1,81-84$ & 1436.7 & + & + & & + & + & & + & & & & & + & \\
\hline $152 \mathrm{R}-1,120-122$ & 1437.1 & + & + & & + & & & + & & & + & & + & \\
\hline$b_{153 R-1,77-79}$ & 1446.1 & + & + & & + & + & & + & & & + & & + & $\mathrm{Mp}$ \\
\hline$b_{154 R-1,116-119}$ & 1455.5 & + & + & & + & + & & + & & & & + & + & \\
\hline b $156 \mathrm{R}-1,37-39$ & 1464.2 & + & + & & & + & & + & + & & + & $r$ & $r$ & \\
\hline $157 \mathrm{R}-1,1-6$ & 1473.1 & + & + & & + & + & & + & & & + & & + & \\
\hline$b_{157 R-1,2-5}$ & 1473.1 & + & + & & + & + & & + & & & & & + & \\
\hline $157 \mathrm{R}-1,8-12$ & 1473.2 & + & + & & + & + & & + & & + & + & & + & \\
\hline$b_{157 R-1,60-63}$ & 1473.7 & + & + & & + & + & & + & + & & + & & + & \\
\hline b $158 \mathrm{R}-1,16-18$ & 1482.7 & + & + & & + & + & & + & + & & + & + & + & \\
\hline b $158 \mathrm{R}-1,18-20$ & 1482.7 & & + & & & + & & + & & & + & + & + & \\
\hline b $158 \mathrm{R}-1,32-34$ & 1482.8 & & + & & & + & + & + & + & + & + & + & + & \\
\hline$b_{158 R-1,30-34}$ & 1482.8 & & + & & & + & + & + & + & + & + & + & + & \\
\hline$b_{159 R-1,27-29}$ & 1488.4 & + & + & & + & + & & + & & & & & + & \\
\hline $159 R-1,52-56$ & 1488.6 & + & + & & + & + & & + & & & + & & + & \\
\hline $160 R-1,25-27$ & 1495.0 & + & + & & + & + & & + & & & & + & + & \\
\hline b $160 R-1,59-60$ & 1495.3 & + & + & & + & + & & + & & & & + & + & \\
\hline $163 \mathrm{R}-1,37-39$ & 1512.0 & + & + & & + & + & & + & & + & + & & & \\
\hline$b_{163 R-1,135-138}$ & 1513.0 & & + & & + & + & & + & & + & & & & \\
\hline $164 R-1,55-58$ & 1515.7 & + & + & & + & + & & + & & & + & & + & \\
\hline$b_{165 \mathrm{R}-1,72-76}$ & 1530.2 & + & + & & + & + & & + & & & & & + & \\
\hline $166 \mathrm{R}-1,8-12$ & 1543.6 & + & + & & + & + & & + & & & + & & & \\
\hline b $169 \mathrm{R}-1,28-31$ & 1547.9 & + & + & + & + & + & & + & & & & + & & \\
\hline$b_{170 R-1,49-53}$ & 1554.1 & + & + & & + & + & & + & + & & & & + & \\
\hline
\end{tabular}

Note: All include small amounts of clay, talc, sulfide, and Fe-Ti oxide.

${ }_{b} \mathrm{Ah}=$ anhydrite $\mathrm{Mp}=$ metamorphic clinopyroxene. 

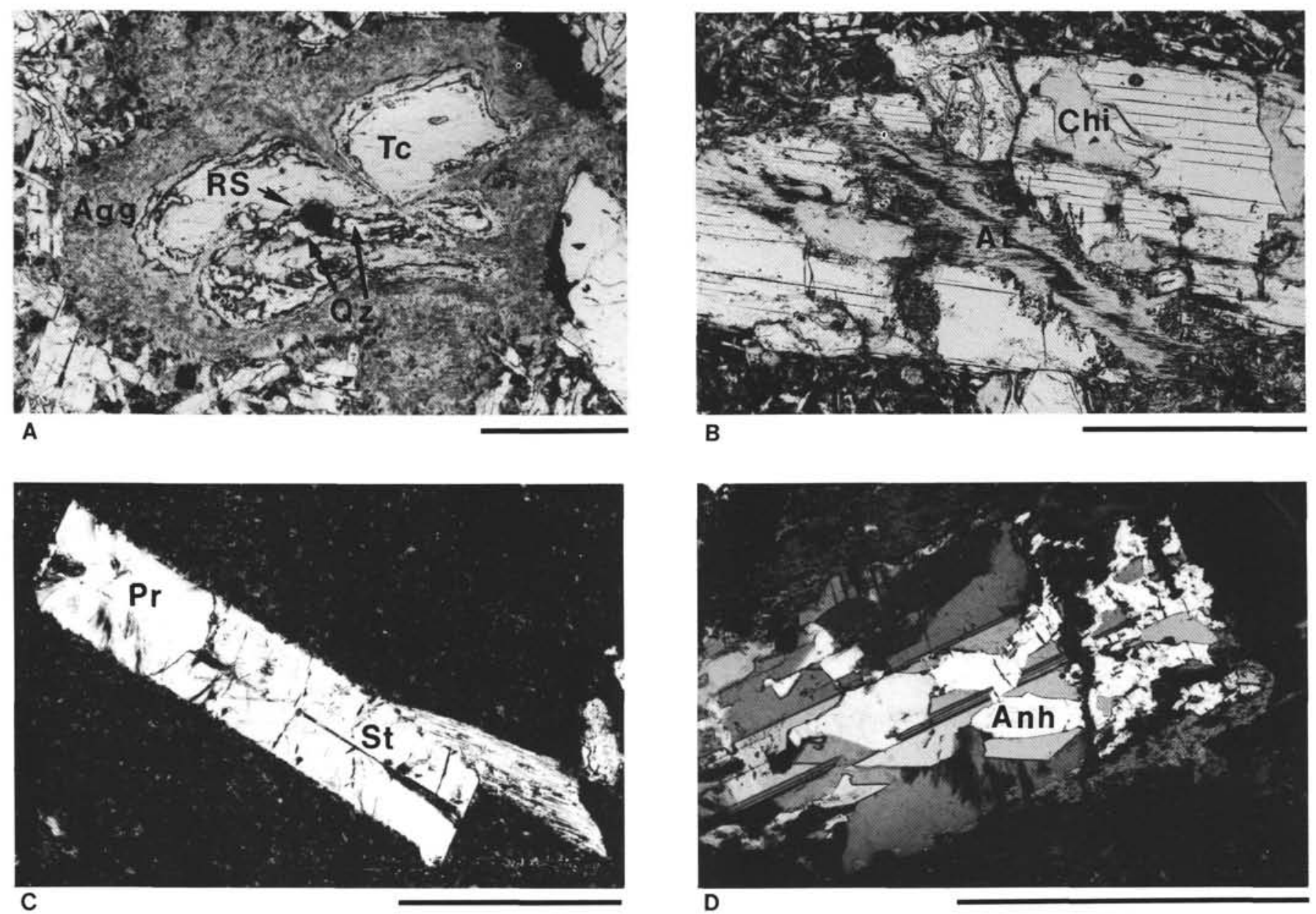

Figure 1. Photomicrographs showing replacement textures of primary (igneous) phases by secondary minerals. The scale bar is $0.5 \mathrm{~mm}$ in length. A. Totally altered olivine phenocryst to talc (Tc), quartz (Qz), and aggregate (Agg) of actinolite and chlorite. A tiny and euhedral crystal of relict Cr spinel (RS) is at the center of the olivine pseudomorph. Sample 111-504B-168R-1, 28-31 cm (plane polarized light). B. Partially altered clinopyroxene phenocryst to actinolite (At) and chlorite (Chl). Sample 111-504B-157R-1, 1-6 cm (plane polarized light). C. Totally altered plagioclase phenocryst to prehnite (Pr) and stilbite (St). Sample 111-504B-142R-1, 118-121 cm (crossed nichols). D. Partially altered plagioclase phenocryst to anhydrite (Anh). Sample 111-504B-152R-1, 17-19 cm (crossed nichols).

chlorites in a single thin section show a rather restricted composition. The compositions of chlorites on the diagram of Hey (1954) plot as dominantly pycnochlorite and less commonly penninite, diabantite, ripidolite, and brunsvigite.

\section{Epidote}

Epidote (Table 6) occurs sporadically only in veins, forming spongy or acicular crystal aggregates. No epidote was found replacing primary minerals such as plagioclase.

The frequency distribution of $\mathrm{XFe}=\mathrm{Fe}^{3+} /\left(\mathrm{Fe}^{3+}+\mathrm{Al}\right)$ of epidote is illustrated in Figure 5. In these samples, the epidotes are relatively homogeneous in relation to the XFe content. Furthermore, the XFe content is apparently higher in epidote associated with laumontite + prehnite than in that with actinolite + prehnite. The $\mathrm{MnO}$ content is negligible, up to $0.10 \mathrm{wt} \%$. The MgO content of some epidotes in Sample 111-504B-158R-1, $30-34 \mathrm{~cm}$, is, however, remarkably high (1.91-1.98 wt \%); such $\mathrm{MgO}-$ rich epidote is tentatively termed "magnesian epidote" by Cho and Liou (1987).

\section{Metamorphic Plagioclase}

Metamorphic plagioclase (Table 7) occurs as discrete patches after plagioclase phenocrysts and groundmass and as fine-grained aggregates in veins and in breccia matrix. Some metamorphic plagioclase replacing primary plagioclase displays a cloudy appearance.

The variations of the An content $=100 \mathrm{Ca} /(\mathrm{Ca}+\mathrm{Na})$ against the $\mathrm{Fe}_{2} \mathrm{O}_{3}{ }^{*}$ and $\mathrm{MgO}$ contents of metamorphic plagioclase are shown in Figure 6, which also includes the compositions of primary plagioclases plotted for comparison. The metamorphic plagioclases are mainly albitic in composition, but there are several plagioclases with oligoclase compositions. Most importantly, the coexistence of albite and oligoclase is found as discrete patches replacing primary plagioclases in Samples 111504B-142R-1, 118-121 cm, 111-504B-149R-2, 50-53 cm, and 111$504 \mathrm{~B}-157 \mathrm{R}-1,1-6 \mathrm{~cm}$, and as fine-grained aggregates in veins in Sample 111-504B-158R-1, 30-34 cm. This may indicate that the "peristerite gap" may occur in Hole 504B. Compared with the compositions of the primary plagioclase, all analyzed metamorphic plagioclases have the lower An content, and also they are poorer in $\mathrm{MgO}$ (less than $0.06 \mathrm{wt} \%$ ) and $\mathrm{Fe}_{2} \mathrm{O}_{3}{ }^{*}$ (less than 0.32 wt $\%$ ). The $\mathrm{K}_{2} \mathrm{O}$ content is very low both in metamorphic (less than $0.06 \mathrm{wt} \%$ ) and primary (less than $0.08 \mathrm{wt} \%$ ) plagioclase.

\section{Amphibole}

Amphibole minerals (Table 8) occur ubiquitously throughout the examined rocks. Most commonly, they are found as acicular to prismatic crystals scattered in pseudomorphs after olivine. 


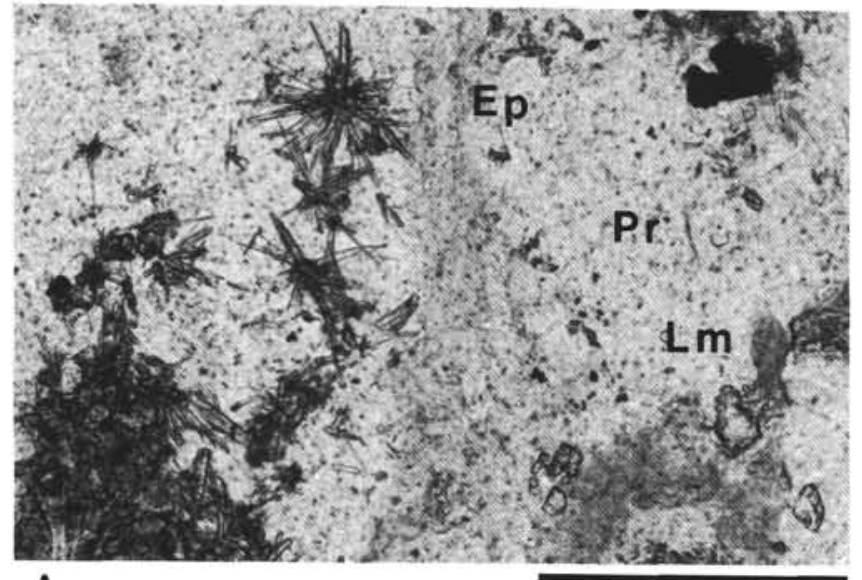

A

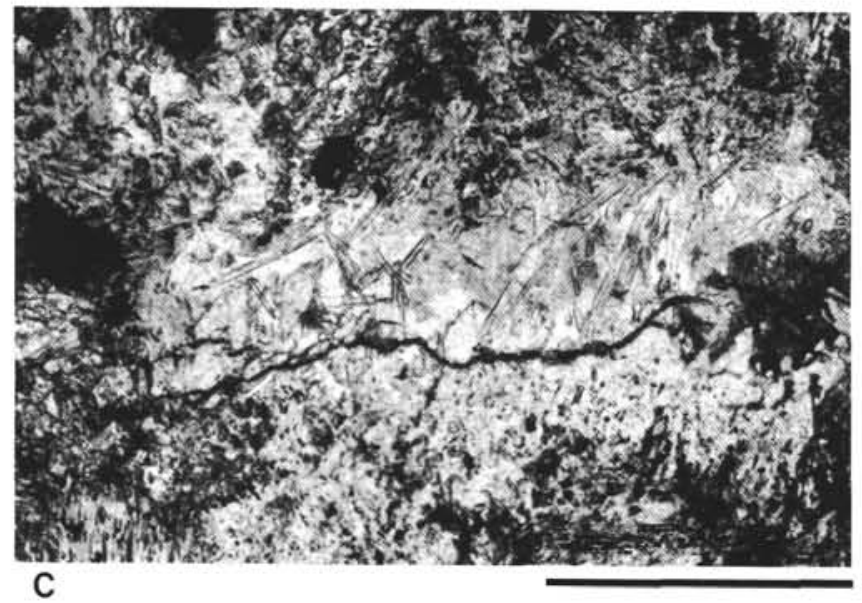

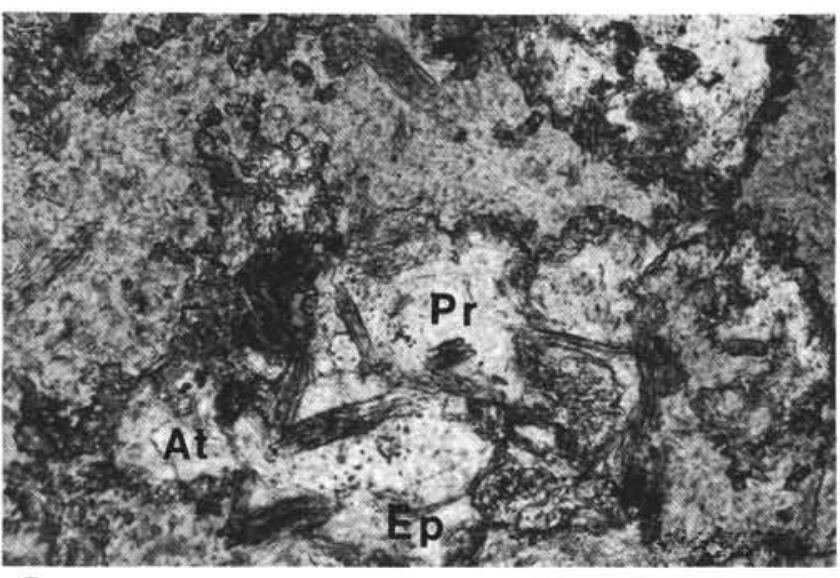

$\mathbf{B}$

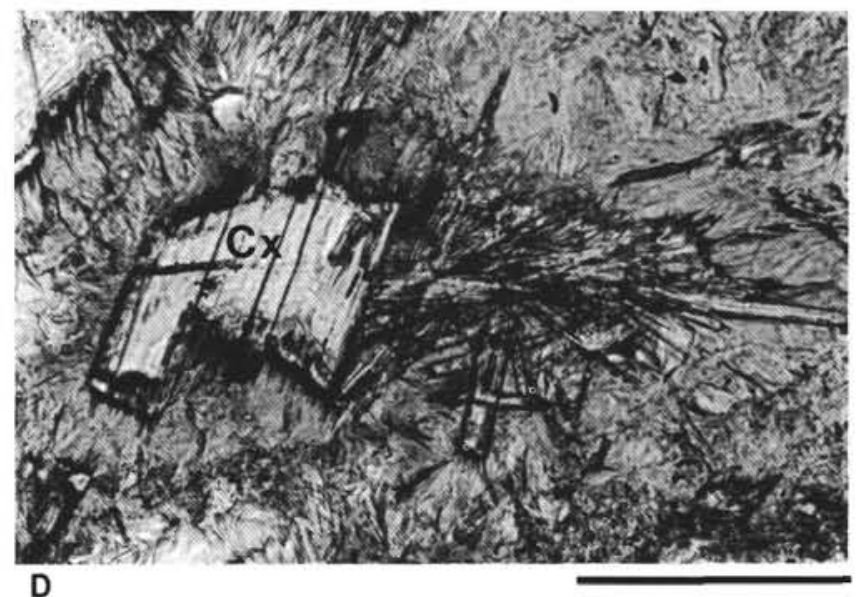

Figure 2. Photomicrographs of veins (all in plane polarized light). The scale bar is $0.2 \mathrm{~mm}$ in length except as noted. A. Prehnite-epidote-laumontite (Pr-Ep-Lm) vein. Sample 111-504B-142R-1, 118-121 cm. B. Prehnite-actinolite-epidote (Pr-At-Ep) vein. Sample 111-504B-158R-1, 32-34 cm. C. Prehnite (white)-actinolite (acicular crystal)-chlorite (gray) vein. Sample 111-504B-152R-1, 5-8 cm. D. Acicular to prismatic sodic augite in chlorite vein. A persisting tabular primary clinopyroxene $(\mathrm{Cx})$ is also slightly altered to chlorite and sodic augite around the margin. Sample 111-504B-152R-1, 61-64 cm. Scale bar is $0.1 \mathrm{~mm}$ in length.

As a partial replacement of primary clinopyroxene they are restricted to the margin around and cracks within clinopyroxene; they take the form of acicular crystals along the margin and fibrous crystal aggregates along the cracks. In veins, fractures, vugs, or breccia matrix acicular to prismatic amphiboles are common, up to $1.0 \mathrm{~mm}$ in length.

The analyzed amphiboles, for which the atomic proportions were calculated on the basis of 23 oxygens, can be divided first into orthorhombic and monoclinic amphiboles.

The orthorhombic amphiboles, which occur only in olivine pseudomorphs in Sample 111-504B-169R-1, 28-31 cm, are mainly composed of $\mathrm{SiO}_{2}, \mathrm{FeO}^{*}$, and $\mathrm{MgO}$. The $\mathrm{Si}$ and $\mathrm{Mg} /(\mathrm{Mg}+\mathrm{Fe})$ values range from 7.92 to 7.95 and from 0.79 to 0.84 , respectively, indicating that these orthorhombic amphiboles can be classified as anthophyllite in the sense of Leake (1978). Besides these major oxides, the anthophyllites contain small amounts of $\mathrm{Al}_{2} \mathrm{O}_{3}$ (up to $0.78 \mathrm{wt} \%$ ), $\mathrm{MnO}$ (up to $0.10 \mathrm{wt} \%$ ), $\mathrm{CaO}$ (up to $0.28 \mathrm{wt} \%$ ), and $\mathrm{Na}_{2} \mathrm{O}$ (up to $0.08 \mathrm{wt} \%$ ).

On the basis of the $(\mathrm{Ca}+\mathrm{Na}) \mathrm{B}$ value of Leake (1978), the monoclinic amphiboles are further divided into $\mathrm{Fe}-\mathrm{Mg}$ amphiboles- $(\mathrm{Ca}+\mathrm{Na}) \mathrm{B}<0.5$ - and $\mathrm{Ca}$ amphiboles- $(\mathrm{Ca}+\mathrm{Na}) \mathrm{B}$ $>0.8$ (Fig. 7). In the sense of Leake (1978), the term Ca amphibole is used where the $(\mathrm{Ca}+\mathrm{Na}) \mathrm{B}$ value is more than 1.34.
However, this value of the Leg $111 \mathrm{Ca}$ amphiboles ranges continuously from 2.0 to 0.8 , and, hence, in this work amphiboles with a $(\mathrm{Ca}+\mathrm{Na}) \mathrm{B}$ value more than 0.8 are termed $\mathrm{Ca}$ amphibole. There is no amphibole with a $(\mathrm{Ca}+\mathrm{Na}) \mathrm{B}$ value intermediate between 0.5 and 0.8 .

The Fe- $\mathrm{Mg}$ amphiboles have $\mathrm{Mg} /(\mathrm{Mg}+\mathrm{Fe})$ values of 0.63 to 0.80 and are classified as magnesiocummingtonite to cummingtonite in the sense of Leake (1978). Besides the major oxides of $\mathrm{SiO}_{2}, \mathrm{FeO}$, and $\mathrm{MgO}$, some $\mathrm{Fe}-\mathrm{Mg}$ amphiboles contain appreciable amounts of $\mathrm{Al}_{2} \mathrm{O}_{3}$ (up to $7.33 \mathrm{wt} \%$ ). These Al-rich Fe-Mg amphiboles are also rich in $\mathrm{TiO}_{2}$ (up to $0.30 \mathrm{wt} \%$ ) and $\mathrm{Na}_{2} \mathrm{O}$ (up to $0.53 \mathrm{wt} \%$ ).

From a plot of compositions on the diagram of Leake (1978) (Fig. 8), the $\mathrm{Ca}$ amphiboles with a $(\mathrm{Ca}+\mathrm{Na}) \mathrm{B}$ value more than 1.34 range dominantly from actinolite or ferroactinolite, through ferroactinolitic hornblende or actinolitic hornblende, to magnesiohornblende; some are scattered in the fields of ferrohornblende, tschermakitic hornblende, ferrotschermakitic hornblende, and tschermakite. The Al-rich calcic amphiboles generally tend to contain appreciable amounts of $\mathrm{TiO}_{2}$ and $\mathrm{Na}_{2} \mathrm{O}$. On the other hand, the $\mathrm{Ca}$ amphiboles with a $(\mathrm{Ca}+\mathrm{Na}) \mathrm{B}$ value less than 1.34, which are not plotted in Figure 8, have both actinolitic $(\mathrm{Si}>7.25)$ and hornblendic $(\mathrm{Si}<7.25)$ compositions 
Table 2. Composition of selected secondary minerals, Hole 504B, ODP Leg 111.

\begin{tabular}{|c|c|c|c|c|c|c|c|c|c|}
\hline $\begin{array}{l}\text { Core, section, } \\
\text { interval }(\mathrm{cm})\end{array}$ & $\begin{array}{l}\text { Depth } \\
\text { (mbsf) }\end{array}$ & Amphibole $^{\mathrm{a}}$ & $\begin{array}{l}\text { Epidote }^{\mathrm{b}} \\
\text { (XFe) }\end{array}$ & $\begin{array}{l}\text { Chlorite }{ }^{c} \\
(\mathrm{XFe})\end{array}$ & $\begin{array}{l}\text { Prehnite } \\
\text { (XFe) }\end{array}$ & Zeolite $^{\mathrm{d}}$ & $\begin{array}{l}\text { Metamorphic } \\
\text { plagioclase } \\
\text { (An-Cont) }\end{array}$ & Quartz & $\begin{array}{l}\text { Sphene }^{f} \\
\text { (XTi) }\end{array}$ \\
\hline $142 \mathrm{R}-1,2-4$ & 1352.8 & $\mathrm{At} / \mathrm{Hb}$ & & $35-36$ & & & & & $89-90$ \\
\hline $142 \mathrm{R}-1,118-121$ & 1354.0 & $\mathrm{At} / \mathrm{Hb}$ & $25-27$ & $37-42$ & $19-13$ & $\mathrm{Lau} / \mathrm{Sti}$ & $4 / 28$ & + & $90-91$ \\
\hline $142 R-2,73-75$ & 1355.0 & At & & $39-42$ & & & 14 & + & \\
\hline $143 R-1,108-112$ & 1360.4 & $\mathrm{Cm} / \mathrm{At}$ & & $32-39$ & & & & + & \\
\hline $144 \mathrm{R}-1,43-47$ & 1369.1 & $\mathrm{Cm} / \mathrm{At} / \mathrm{Hb}$ & & $30-34$ & & & & & \\
\hline $145 \mathrm{R}-3,137-138$ & 1384.2 & $\mathrm{Cm} / \mathrm{At} / \mathrm{Hb}$ & & & & & & + & \\
\hline $147 R-2,30-33$ & 1399.2 & At & & $39-58$ & & Lau & & & $71-72$ \\
\hline $149 \mathrm{R}-2,50-53$ & 1418.9 & At & & $40-44$ & $10-11$ & Sti & $3 / 19$ & + & \\
\hline 149R-2, 57-59 & 1419.0 & At & & $38-39$ & & Lau & & & \\
\hline 150R-1, $81-83$ & 1427.2 & At & & $39-40$ & & & & & \\
\hline $152 \mathrm{R}-1,5-8$ & 1436.0 & $\mathrm{At} / \mathrm{Hb}$ & & $43-44$ & $10-11$ & & 3 & & \\
\hline $152 \mathrm{R}-1,17-19$ & 1436.1 & $\mathrm{At} / \mathrm{Hb}$ & & $41-45$ & $2-3$ & $\mathrm{Lau} / \mathrm{Sti}$ & $6 / 7$ & & \\
\hline $152 \mathrm{R}-1,61-64$ & 1436.5 & At & & $40-41$ & & & $3 / 4$ & & \\
\hline $153 \mathrm{R}-1,77-79$ & 1446.1 & At & & $41-51$ & & & $2 / 3$ & & $79-82$ \\
\hline $154 \mathrm{R}-1,116-119$ & 1455.5 & At & & $42-45$ & & & & + & $85-92$ \\
\hline $156 \mathrm{R}-1,37-39$ & 1464.2 & $\mathrm{At} / \mathrm{Hb}$ & & $42-43$ & $5-13$ & & 11 & & \\
\hline $157 R-1,1-6$ & 1473.1 & At & & $37-46$ & & & $4 / 11 / 19$ & & \\
\hline $157 \mathrm{R}-1,2-5$ & 1473.1 & At & & $40-41$ & & & & & \\
\hline $157 \mathrm{R}-1,60-63$ & 1473.7 & At & & $40-41$ & $6-14$ & & $2 / 3 / 4 / 5$ & & \\
\hline $158 \mathrm{R}-1,16-18$ & 1482.7 & At & & $40-41$ & & & 9 & + & \\
\hline $158 \mathrm{R}-1,18-20$ & 1482.7 & At & & $40-42$ & & & $11 / 13$ & + & $86-87$ \\
\hline $158 \mathrm{R}-1,32-34$ & 1482.8 & At & $19-21$ & $45-46$ & $9-10$ & Lau & & + & \\
\hline $158 \mathrm{R}-1,30-34$ & 1482.8 & At & $16-21$ & $42-44$ & $7-8$ & $\mathrm{Lau} / \mathrm{Sti}$ & $3 / 4 / 4 / 4 / 20$ & + & $88-93$ \\
\hline $159 \mathrm{R}-1,27-29$ & 1488.4 & At & & $40-45$ & & & & & \\
\hline $159 \mathrm{R}-1,52-56$ & 1488.6 & $\mathrm{At} / \mathrm{Hb}$ & & $46-51$ & & & & + & $85-88$ \\
\hline $160 \mathrm{R}-1,25-27$ & 1495.0 & At & & $39-40$ & & & & + & $82-88$ \\
\hline $160 \mathrm{R}-1,59-60$ & 1495.3 & At & & $37-46$ & & & & + & $86-88$ \\
\hline $163 \mathrm{R}-1,135-138$ & 1513.0 & $\mathrm{Hb}$ & & $42-51$ & & $\mathrm{Lau} / \mathrm{Sti}$ & & & \\
\hline $164 \mathrm{R}-\mathrm{I}, 55-58$ & 1515.7 & $\mathrm{At} / \mathrm{Hb}$ & & $37-42$ & & & 8 & & \\
\hline $165 \mathrm{R}-1,72-76$ & 1530.2 & At & & $39-40$ & & & & & \\
\hline $169 \mathrm{R}-1,28-31$ & 1547.9 & $\begin{array}{c}\mathrm{Ap} / \mathrm{Cm} / \\
\mathrm{At} / \mathrm{Hb}\end{array}$ & & $39-41$ & & & & + & \\
\hline $170 R-1,49-53$ & 1554.1 & $\mathrm{At} / \mathrm{Hb}$ & & $41-47$ & $4-5$ & & & & $84-90$ \\
\hline
\end{tabular}

Note: All include small amounts of clay, talc, sulfide, and Fe-Ti oxide.

at $=$ actinolite; $\mathrm{Hb}=$ hornblende $; \mathrm{Cm}=$ cummingtonite; $\mathrm{Ap}=$ anthophyllite.

b $\mathrm{XFe}=100 \mathrm{Fe}^{3+} /\left(\mathrm{Fe}^{3+}+\mathrm{Al}\right)$.

${ }^{\mathrm{X}} \mathrm{XFe}=100 \mathrm{Fe}^{2+} /\left(\mathrm{Fe}^{2+}+\mathrm{Mg}\right)$.

${ }^{d}$ Lau $=$ laumontite; $\mathrm{Sti}=$ stilbite.

e An-Cont $=100 \mathrm{Ca} /(\mathrm{Ca}+\mathrm{Na})$.

$\mathrm{XTi}=100 \mathrm{Ti} /\left(\mathrm{Ti}+\mathrm{Al}+\mathrm{Fe}^{2+}\right)$.

Table 3. Representative zeolite analyses, Hole 504B, ODP Leg 111.

\begin{tabular}{|c|c|c|c|c|c|c|c|c|c|}
\hline Species & $\begin{array}{l}\text { Core, section, } \\
\text { interval }(\mathrm{cm})\end{array}$ & $\begin{array}{l}\text { Depth } \\
\text { (mbsf) }\end{array}$ & $\mathrm{SiO}_{2}$ & $\mathrm{Al}_{2} \mathrm{O}_{3}$ & $\mathrm{Fe}_{2} \mathrm{O}_{3}{ }^{\mathrm{a}}$ & $\mathrm{CaO}$ & $\mathrm{Na}_{2} \mathrm{O}$ & $\mathrm{K}_{2} \mathrm{O}$ & Total \\
\hline \multirow[t]{9}{*}{ Laumontite } & $142 \mathrm{R}-1,118-121$ & 1354.0 & 52.18 & 22.27 & 0.13 & 12.01 & 0.13 & 0.01 & 86.73 \\
\hline & & & 53.98 & 20.70 & 0.26 & 11.28 & 0.51 & 0.07 & 86.80 \\
\hline & $147 \mathrm{R}-2,30-33$ & 1399.2 & 54.46 & 20.88 & 0.00 & 11.07 & 0.37 & 0.04 & 86.82 \\
\hline & $149 \mathrm{R}-2,57-59$ & 1419.0 & 53.51 & 20.98 & 0.00 & 10.98 & 0.58 & 0.00 & 86.05 \\
\hline & & & 53.71 & 20.94 & 0.00 & 11.18 & 0.66 & 0.00 & 86.49 \\
\hline & $158 \mathrm{R}-1,30-34$ & 1482.8 & 54.37 & 21.97 & 0.22 & 11.16 & 0.22 & 0.00 & 87.94 \\
\hline & & & 53.88 & 21.74 & 0.10 & 11.50 & 0.20 & 0.04 & 87.46 \\
\hline & $163 \mathrm{R}-1,135-138$ & 1513.0 & 55.22 & 21.38 & 0.02 & 10.94 & 0.44 & 0.08 & 88.08 \\
\hline & & & 54.22 & 20.88 & 0.07 & 10.65 & 0.39 & 0.08 & 86.29 \\
\hline \multirow{10}{*}{ Stilbite } & $142 \mathrm{R}-1,118-121$ & 1354.0 & 57.90 & 16.18 & 0.07 & 8.70 & 0.23 & 0.02 & 83.10 \\
\hline & & & 58.83 & 16.95 & 0.00 & 9.25 & 0.28 & 0.00 & 85.31 \\
\hline & $149 \mathrm{R}-2,50-53$ & 1418.9 & 59.85 & 16.69 & 0.50 & 8.90 & 0.18 & 0.04 & 86.16 \\
\hline & $152 \mathrm{R}-1,17-19$ & 1436.1 & 59.53 & 15.98 & 0.07 & 8.31 & 0.18 & 0.02 & 84.09 \\
\hline & & & 59.75 & 16.49 & 0.02 & 8.88 & 0.21 & 0.05 & 85.40 \\
\hline & $152 \mathrm{R}-1,61-64$ & 1436.5 & 59.31 & 14.74 & 0.04 & 8.49 & 0.21 & 0.02 & 82.81 \\
\hline & $158 \mathrm{R}-1,30-34$ & 1482.8 & 58.23 & 17.82 & 0.10 & 9.45 & 0.14 & 0.05 & 85.79 \\
\hline & & & 57.30 & 18.62 & 0.05 & 9.46 & 0.24 & 0.04 & 85.71 \\
\hline & $163 \mathrm{R}-1,135-138$ & 1513.0 & 56.75 & 17.36 & 0.17 & 8.99 & 0.29 & 0.02 & 83.58 \\
\hline & & & 57.21 & 18.51 & 0.03 & 9.60 & 0.21 & 0.01 & 85.57 \\
\hline
\end{tabular}

${ }^{\text {a }}$ Total iron as $\mathrm{Fe}_{2} \mathrm{O}_{3}$.

with the $\mathrm{Mg} /(\mathrm{Mg}+\mathrm{Fe})$ ratio ranging from 0.33 to 0.69 and from 0.53 to 0.64 , respectively. Such amphiboles have been rarely reported in the literature (e.g., Robinson et al., 1982).

For these $\mathrm{Ca}$ amphiboles, especially for the actinolitic $\mathrm{Ca}$ amphiboles, considerable variations are typically found in (Fe
$+\mathrm{Mg}$ ) and $\mathrm{Ca}$ (Fig. 9), and there is a negative correlation between $(\mathrm{Fe}+\mathrm{Mg})$ and $\mathrm{Ca}$. This may indicate that significant substitution of $\mathrm{Ca}$ for $(\mathrm{Fe}+\mathrm{Mg})$ occurs.

The following pairs of amphibole species were occasionally observed as coexisting as discrete crystals in a single vein or vug 
Table 4. Representative prehnite analyses, Hole 504B, ODP Leg 111.

\begin{tabular}{|c|c|c|c|c|c|c|c|c|c|c|c|}
\hline \multirow{2}{*}{$\begin{array}{l}\text { Core, section, } \\
\text { interval }(\mathrm{cm})\end{array}$} & \multirow{2}{*}{$\begin{array}{l}\text { Depth } \\
\text { (mbsf) }\end{array}$} & \multirow[b]{2}{*}{$\mathrm{SiO}_{2}$} & \multirow[b]{2}{*}{$\mathrm{TiO}_{2}$} & \multirow[b]{2}{*}{$\mathrm{Al}_{2} \mathrm{O}_{3}$} & \multirow[b]{2}{*}{$\mathrm{Fe}_{2} \mathrm{O}_{3}{ }^{\mathrm{a}}$} & \multirow[b]{2}{*}{$\mathrm{MnO}$} & \multirow[b]{2}{*}{$\mathrm{MgO}$} & \multirow[b]{2}{*}{$\mathrm{CaO}$} & \multirow[b]{2}{*}{$\mathrm{Na}_{2} \mathrm{O}$} & \multirow[b]{2}{*}{ Total } & $\mathrm{Fe}^{3+}$ \\
\hline & & & & & & & & & & & $\overline{\left(\mathrm{Fe}^{3+}+\mathrm{Al}\right)}$ \\
\hline \multirow[t]{2}{*}{$142 \mathrm{R}-1,118-121$} & 1354.0 & 43.71 & 0.00 & 19.85 & 7.30 & 0.00 & 0.05 & 25.26 & 0.03 & 96.20 & 0.19 \\
\hline & & 43.77 & 0.01 & 21.45 & 5.07 & 0.03 & 0.02 & 26.62 & 0.09 & 97.06 & 0.13 \\
\hline $149 \mathrm{R}-2,50-53$ & 1418.9 & 43.72 & 0.00 & 22.16 & 4.18 & 0.00 & 0.31 & 25.58 & 0.09 & 96.04 & 0.11 \\
\hline $152 \mathrm{R}-1,5-8$ & 1436.0 & 42.56 & 0.00 & 21.47 & 4.21 & 0.00 & 0.00 & 26.00 & 0.00 & 94.24 & 0.11 \\
\hline $152 \mathrm{R}-1,17-19$ & 1436.1 & 43.53 & 0.02 & 25.01 & 0.97 & 0.00 & 0.03 & 26.57 & 0.00 & 96.13 & 0.02 \\
\hline \multirow[t]{2}{*}{$156 \mathrm{R}-1,37-39$} & 1464.2 & 43.69 & 0.00 & 21.60 & 5.04 & 0.00 & 0.03 & 26.18 & 0.07 & 96.61 & 0.13 \\
\hline & & 43.64 & 0.09 & 23.32 & 3.03 & 0.00 & 0.04 & 26.25 & 0.03 & 96.40 & 0.08 \\
\hline \multirow[t]{2}{*}{$157 \mathrm{R}-1,60-63$} & 1473.2 & 43.50 & 0.00 & 21.53 & 5.02 & 0.00 & 0.01 & 26.26 & 0.08 & 96.40 & 0.13 \\
\hline & & 44.14 & 0.02 & 23.62 & 2.36 & 0.07 & 0.01 & 26.23 & 0.03 & 96.48 & 0.06 \\
\hline $158 \mathrm{R}-1,32-34$ & 1482.8 & 44.29 & 0.00 & 22.38 & 3.27 & 0.00 & 0.00 & 25.81 & 0.04 & 95.79 & 0.08 \\
\hline \multirow[t]{2}{*}{$158 \mathrm{R}-1,30-34$} & 1482.8 & 43.94 & 0.00 & 22.38 & 2.96 & 0.00 & 0.02 & 25.71 & 0.09 & 95.10 & 0.08 \\
\hline & & 44.08 & 0.03 & 22.74 & 2.71 & 0.00 & 0.00 & 25.87 & 0.04 & 95.47 & 0.07 \\
\hline $170 \mathrm{R}-1,49-53$ & 1554.1 & 43.29 & 0.00 & 23.87 & 1.76 & 0.02 & 0.25 & 26.25 & 0.00 & 95.44 & 0.04 \\
\hline
\end{tabular}

a Total iron as $\mathrm{Fe}_{2} \mathrm{O}_{3}$.

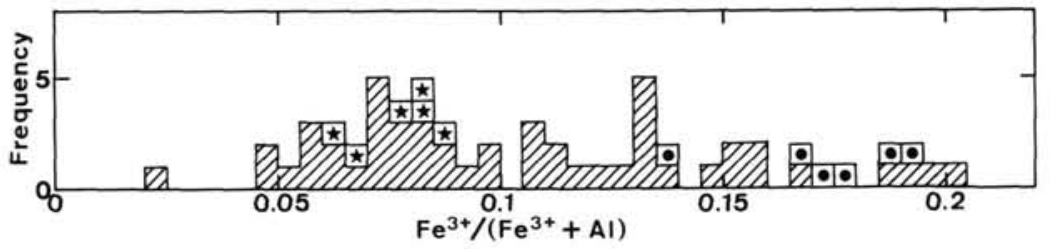

Figure 3. Frequency distribution of the $\mathrm{Fe}^{3+} /\left(\mathrm{Fe}^{3+}+\mathrm{Al}\right)$ ratio for prehnite. Dots and stars represent analyses of prehnites coexisting with epidote and laumontite and with epidote and actinolite, respectively.

or olivine pseudomorph: actinolite + hornblende (Samples 111-504B-142R-1, 2-4 cm, and 111-504B-142R-1, 118-121 cm, 111-504B-159R-1, 52-56 cm, and 111-504B-170R-1, 49-53 cm), actinolite-cummingtonite (Samples 111-504B-144R-1, 43-47 cm, and 111-504B-169R-1, 28-31 cm), hornblende + cummingtonite (Sample 111-504B-145R-3, 137-138 cm), and hornblende + cummingtonite + anthophyllite (Sample 111-504B-169R-1, 28$31 \mathrm{~cm}$ ). This may reflect the compositional gap between each amphibole pair (Robinson et al., 1982).

A preliminary analysis of chlorine using EDS indicates that the amphiboles are enriched in $\mathrm{Cl}$ content, up to $0.2 \mathrm{wt} \%$, and further, that in the same thin section, the $\mathrm{Cl}$ content is higher in amphiboles filling veins than in those replacing clinopyroxene. This may suggest the presence of a saline hydrothermal fluid or a fluid of near seawater salinity (Vanko, 1986).

\section{Other Secondary Minerals}

Other secondary minerals analyzed here include sodic augite, sphene, talc, anhydrite, chalcopyrite, pyrite, and Fe-Ti oxide (Table 9); sulfur of anhydrite, chalcopyrite, and pyrite were not analyzed.

\section{Sodic Augite}

Sodic augite is found only in veins from Samples 111-504B152R-1, 61-64 cm, and 111-504B-153R-1, 77-79 cm, taking the form of acicular crystal aggregates. Compared with the primary clinopyroxene in the same thin section, the sodic augite is higher in $\mathrm{Al}_{2} \mathrm{O}_{3}, \mathrm{CaO}$, and $\mathrm{Na}_{2} \mathrm{O}$ and lower in $\mathrm{TiO}_{2}$ and $\mathrm{MgO}$. One of the analyzed sodic augites is, however, rich in the $\mathrm{TiO}_{2}$ content $(2.47 \mathrm{wt} \%)$. Laverne (1983) described aegirine-augite from 298 $\mathrm{m}$ below the top of basement recovered from Hole 504B during DSDP Leg 70. Compared with the aegirine-augite compositions of Leg 70, the sodic augite recovered during Leg 111 is richer in $\mathrm{Al}_{2} \mathrm{O}_{3}$ and poorer in $\mathrm{FeO}^{*}$ and $\mathrm{Na}_{2} \mathrm{O}$.

\section{Sphene}

Sphene occurs commonly as dusty aggregates intimately associated with opaque phases and as individual anhedral grains of less than $0.5 \mathrm{~mm}$ diameter scattered in veins, vugs, and breccia matrix. The analyses of sphene exhibit relatively constant proportions of $\mathrm{SiO}_{2}(29.8-31.2 \mathrm{wt} \%)$ and $\mathrm{CaO}(27.0-28.0 \mathrm{wt} \%)$, but show some variations of $\mathrm{TiO}_{2}(29.2-37.7 \mathrm{wt} \%), \mathrm{Al}_{2} \mathrm{O}_{3}(1.3-$ $6.4 \mathrm{wt} \%)$, and $\mathrm{FeO}^{*}(0.7-2.5 \mathrm{wt} \%)$. All other analyzed elements $\left(\mathrm{Cr}_{2} \mathrm{O}_{3}, \mathrm{MnO}, \mathrm{MgO}, \mathrm{Na}_{2} \mathrm{O}\right.$, and $\left.\mathrm{K}_{2} \mathrm{O}\right)$ occur in insignificant amounts.

\section{Talc}

Talc, which is generally restricted to platy crystal aggregates in pseudomorphs after olivine, is mainly composed of $\mathrm{SiO}_{2}$ and $\mathrm{MgO}$, but also contains appreciable amounts of $\mathrm{Al}_{2} \mathrm{O}_{3}$ and $\mathrm{FeO}^{*}$, up to 4.2 and $9.7 \mathrm{wt} \%$, respectively. Of these elements, the $\mathrm{Al}_{2} \mathrm{O}_{3}$ and $\mathrm{FeO} *$ contents vary antithetically to the $\mathrm{SiO}_{2}$ and $\mathrm{MgO}$ contents, respectively. This suggests $\mathrm{Al}-\mathrm{Si}$ and $\mathrm{Fe}-\mathrm{Mg}$ substitutions.

\section{Anhydrite}

Anhydrite, found in Samples 111-504B-152R-1, 17-19 cm, and 111-504B-152R-1, 61-64 cm, as discrete patches after plagioclase phenocrysts, contains a $\mathrm{CaO}$ content of 37.8-39.7 wt \% with little or no amounts of other oxides present.

\section{Chalcopyrite and Pyrite}

Chalcopyrite and pyrite, commonly replacing primary magnetite and rarely rimming olivine pseudomorphs, have $\mathrm{FeO}^{*}$ contents of $39.7-44.3$ and $59.0-60.9 \mathrm{wt} \%$, respectively. Other oxides in these sulfide minerals occur in insignificant amounts, but some of the $\mathrm{Na}_{2} \mathrm{O}$ content is enriched, up to $0.54 \mathrm{wt} \%$ in chalcopyrite and $0.36 \mathrm{wt} \%$ in pyrite. 
Table 5. Representative chlorite analyses, Hole 504B, ODP Leg 111.

\begin{tabular}{|c|c|c|c|c|c|c|c|c|c|c|}
\hline \multirow{2}{*}{$\begin{array}{l}\text { Core, section, } \\
\text { interval }(\mathrm{cm})\end{array}$} & \multirow{2}{*}{$\begin{array}{l}\text { Depth } \\
\text { (mbsf) }\end{array}$} & \multirow[b]{2}{*}{$\mathrm{SiO}_{2}$} & \multirow[b]{2}{*}{$\mathrm{Al}_{2} \mathrm{O}_{3}$} & \multirow[b]{2}{*}{$\mathrm{FeO}^{* a}$} & \multirow[b]{2}{*}{$\mathrm{MnO}$} & \multirow[b]{2}{*}{$\mathrm{MgO}$} & \multirow[b]{2}{*}{$\mathrm{CaO}$} & \multirow[b]{2}{*}{ Total } & $\mathrm{Fe}^{2+}$ & \multirow[b]{2}{*}{ Species $^{b}$} \\
\hline & & & & & & & & & $\overline{\left(\mathrm{Fe}^{2+}+\mathrm{Mg}\right)}$ & \\
\hline $142 \mathrm{R}-1,2-4$ & 1352.8 & 29.67 & 19.12 & 19.49 & 0.12 & 19.34 & 0.12 & 87.86 & 0.36 & Pycno. \\
\hline $142 \mathrm{R}-1,118-121$ & 1354.0 & 28.10 & 19.46 & 21.23 & 0.20 & 17.72 & 0.14 & 86.85 & 0.40 & Pycno. \\
\hline \multirow[t]{2}{*}{$142 \mathrm{R}-2,73-75$} & 1355.0 & 29.65 & 17.35 & 22.49 & 0.11 & 17.31 & 0.31 & 87.22 & 0.42 & Pycno. \\
\hline & & 29.74 & 15.41 & 22.17 & 0.10 & 18.03 & 0.19 & 85.64 & 0.41 & Diaba. \\
\hline $143 R-1,108-112$ & 1360.4 & 26.66 & 15.53 & 20.53 & 0.19 & 21.26 & 0.23 & 84.40 & 0.35 & Pycno. \\
\hline $144 \mathrm{R}-1,43-47$ & 1369.1 & 31.94 & 14.71 & 17.23 & 0.11 & 23.04 & 0.24 & 87.27 & 0.30 & Diaba. \\
\hline \multirow[t]{2}{*}{$147 \mathrm{R}-2,30-33$} & 1399.2 & 28.33 & 15.09 & 28.07 & 0.20 & 14.69 & 0.16 & 86.54 & 0.52 & Bruns. \\
\hline & & 29.29 & 17.52 & 21.91 & 0.25 & 19.60 & 0.17 & 88.74 & 0.39 & Pycno. \\
\hline $149 \mathrm{R}-2,50-53$ & 1418.9 & 27.77 & 18.31 & 24.03 & 0.17 & 16.85 & 0.02 & 87.15 & 0.44 & Pycno. \\
\hline $149 \mathrm{R}-2,57-59$ & 1419.0 & 26.50 & 17.90 & 20.08 & 0.00 & 18.21 & 0.18 & 82.87 & 0.38 & Pycno. \\
\hline $150 \mathrm{R}-1,81-83$ & 1427.2 & 27.30 & 17.70 & 20.95 & 0.00 & 18.40 & 0.25 & 84.60 & 0.39 & Pycno. \\
\hline $152 \mathrm{R}-1,5-8$ & 1436.0 & 26.68 & 18.52 & 22.40 & 0.21 & 16.88 & 0.00 & 84.69 & 0.43 & Pycno. \\
\hline $152 \mathrm{R}-1,17-19$ & & 28.42 & 17.37 & 23.72 & 0.18 & 17.55 & 0.08 & 87.32 & 0.43 & Pycno. \\
\hline $152 \mathrm{R}-1,61-64$ & 1436.5 & 31.19 & 16.59 & 21.89 & 0.16 & 18.97 & 0.44 & 89.24 & 0.39 & Diaba. \\
\hline \multirow{2}{*}{$153 \mathrm{R}-1,77-79$} & 1446.1 & 27.39 & 18.77 & 22.60 & 0.18 & 17.53 & 0.07 & 86.54 & 0.42 & Pycno. \\
\hline & & 26.80 & 19.54 & 26.39 & 0.31 & 13.87 & 0.24 & 87.15 & 0.52 & Bruns. \\
\hline $154 \mathrm{R}-1,116-119$ & 1455.5 & 26.96 & 18.75 & 23.29 & 0.19 & 17.54 & 0.09 & 86.82 & 0.43 & Pycno. \\
\hline $156 \mathrm{R}-1,37-39$ & 1464.2 & 27.93 & 19.30 & 23.05 & 0.19 & 17.63 & 0.21 & 88.31 & 0.42 & Pycno. \\
\hline \multirow[t]{2}{*}{$157 \mathrm{R}-1,1-6$} & 1473.1 & 27.47 & 18.92 & 22.01 & 0.19 & 17.59 & 0.08 & 86.26 & 0.41 & Pycno. \\
\hline & & 26.81 & 19.19 & 21.69 & 0.23 & 18.58 & 0.06 & 86.56 & 0.40 & Ripid. \\
\hline $157 \mathrm{R}-1,2-5$ & 1473.1 & 27.50 & 16.93 & 20.91 & 0.00 & 17.86 & 0.21 & 83.41 & 0.40 & Pycno. \\
\hline $157 R-1,60-63$ & 1473.7 & 27.14 & 17.84 & 21.03 & 0.15 & 17.94 & 0.31 & 84.41 & 0.40 & Pycno. \\
\hline $158 \mathrm{R}-1,16-18$ & 1482.7 & 27.86 & 17.37 & 21.56 & 0.00 & 18.08 & 0.33 & 85.20 & 0.40 & Pycno. \\
\hline $158 \mathrm{R}-1,18-20$ & 1482.7 & 27.96 & 18.18 & 23.45 & 0.07 & 18.20 & 0.13 & 87.99 & 0.42 & Pycno. \\
\hline $158 \mathrm{R}-1,32-34$ & 1482.8 & 26.88 & 17.98 & 23.64 & 0.00 & 16.18 & 0.26 & 84.94 & 0.45 & Pycno. \\
\hline \multirow[t]{2}{*}{$158 \mathrm{R}-1,30-34$} & 1482.8 & 27.79 & 19.77 & 23.53 & 0.26 & 17.08 & 0.27 & 88.70 & 0.44 & Pycno. \\
\hline & & 26.79 & 19.67 & 24.21 & 0.23 & 17.05 & 0.18 & 88.13 & 0.44 & Ripid. \\
\hline $159 \mathrm{R}-1,27-29$ & 1488.4 & 27.69 & 18.74 & 23.76 & 0.13 & 16.30 & 0.15 & 86.77 & 0.45 & Pycno. \\
\hline \multirow[t]{2}{*}{$159 \mathrm{R}-1,52-56$} & 1488.6 & 27.11 & 16.41 & 27.77 & 0.16 & 14.73 & 0.10 & 86.28 & 0.51 & Bruns. \\
\hline & & 26.61 & 17.88 & 24.68 & 0.19 & 16.28 & 0.06 & 85.70 & 0.46 & Pycno. \\
\hline $160 \mathrm{R}-1,25-27$ & 1495.0 & 27.21 & 19.59 & 21.13 & 0.25 & 18.78 & 0.09 & 87.05 & 0.39 & Pycno. \\
\hline $160 \mathrm{R}-1,59-60$ & 1495.3 & 27.02 & 19.17 & 20.88 & 0.15 & 18.78 & 0.09 & 86.09 & 0.38 & Pycno. \\
\hline \multirow[t]{2}{*}{$163 \mathrm{R}-1,135-138$} & 1513.0 & 27.08 & 18.22 & 27.32 & 0.15 & 14.92 & 0.15 & 87.84 & 0.51 & Bruns. \\
\hline & & 27.92 & 18.18 & 23.44 & 0.18 & 17.19 & 0.13 & 87.04 & 0.43 & Pycno. \\
\hline $164 \mathrm{R}-1,55-58$ & 1515.7 & 27.77 & 20.24 & 20.29 & 0.13 & 19.17 & 0.11 & 87.71 & 0.37 & Pycno. \\
\hline $165 \mathrm{R}-1,72-76$ & 1530.2 & 28.11 & 18.61 & 21.15 & 0.12 & 17.94 & 0.16 & 86.09 & 0.40 & Pyeno. \\
\hline \multirow[t]{2}{*}{$169 \mathrm{R}-1,28-31$} & 1547.9 & 27.41 & 16.63 & 21.57 & 0.27 & 19.11 & 0.15 & 85.14 & 0.39 & Pycno. \\
\hline & & 28.70 & 16.64 & 20.42 & 0.10 & 16.52 & 0.36 & 82.74 & 0.41 & Diaba. \\
\hline $170 \mathrm{R}-1,49-53$ & 1554.1 & 26.64 & 18.79 & 23.63 & 0.14 & 16.92 & 0.05 & 86.17 & 0.44 & Pycno. \\
\hline
\end{tabular}

a Total iron as FeO.

${ }^{\mathrm{b}}$ Pycno. = pycnochlorite; Diaba. = diabantite; Bruns. = brunsvigite; Ripid. = ripidolite.

\section{$\mathrm{Fe}$-Ti Oxide}

Fe-Ti oxide, mainly occurring as partial or total replacement of primary opaque phases such as $\mathrm{Cr}$ spinel and magnetite, exhibits wide variations in major oxides; the $\mathrm{TiO}_{2}$ contents range from 28.4 to $11.2 \mathrm{wt} \%$, and the $\mathrm{FeO}^{*}$ contents range from 53.6 to $77.0 \mathrm{wt} \%$.

\section{MINERAL PARAGENESIS}

The mineral assemblages observed in the altered basalts from Hole 504B can be generally represented by the model chemical system $\mathrm{SiO}_{2}-\mathrm{TiO}_{2}-\mathrm{Al}_{2} \mathrm{O}_{3}-\mathrm{Fe}_{2} \mathrm{O}_{3}-\mathrm{FeO}-\mathrm{MgO}-\mathrm{CaO}-\mathrm{Na}_{2} \mathrm{O}-\mathrm{H}_{2} \mathrm{O}$, assuming that $\mathrm{MnO}$ (up to $0.20 \mathrm{wt} \%$ ) and $\mathrm{K}_{2} \mathrm{O}$ (up to $0.05 \mathrm{wt} \%$ ) are minor components (shipboard X-ray-fluorescence analyses; Shipboard Scientific Party, 1988). $\mathrm{SiO}_{2}, \mathrm{TiO}_{2}$, and $\mathrm{Na}_{2} \mathrm{O}$ are assumed to be fixed in quartz, sphene, and sodic plagioclase, respectively. If the fluid phase is assumed to be in excess and consisting mainly of $\mathrm{H}_{2} \mathrm{O}, \mathrm{H}_{2} \mathrm{O}$ can be considered a perfectly mobile component. Furthermore, if the chlorite composition is fixed at constant $\mathrm{Fe} /(\mathrm{Fe}+\mathrm{Mg})$, the system can be simplified to the four components $\mathrm{Al}_{2} \mathrm{O}_{3}-\mathrm{Fe}_{2} \mathrm{O}_{3}-(\mathrm{Fe} / \mathrm{Mg}) \mathrm{O}-\mathrm{CaO}$ (Fig. 10A). In order to graphically evaluate the mineral paragenesis and the effect of $\mathrm{Al}-\mathrm{Fe}^{3+}$ substitution in $\mathrm{Ca}-\mathrm{Al}$ silicates (epidote and prehnite), the chlorite projection onto the $\mathrm{Al}_{2} \mathrm{O}_{3}(\mathrm{~A})-\mathrm{Fe}_{2} \mathrm{O}_{3}(\mathrm{~F})$ $\mathrm{CaO}(\mathrm{C})$ plane as described by Liou et al. (1985a) is adopted in this study (Fig. 10B), mainly because chlorite is ubiquitous in the samples.
The mineral associations and chemistries in the samples examined here generally show some variations from place to place in each thin section. Such variations, which can be attributed to local differences in effective bulk compositions, make it difficult to define the equilibrium compositions and compatibilities of the coexisting minerals in very low-grade metamorphic rocks (e.g., Liou et al., 1987). In this case, minerals in contact are generally assumed to represent equilibrium, as suggested by Zen (1974). In fact, it is extremely difficult to find two or three CaAl silicates together with chlorite, albite and/or oligoclase, quartz, and sphene in a contact relationship in an assumed equilibrium domain. For the practical purposes of the present study, therefore, the analyzed compositions for a group of minerals within veins or fractures $1-10 \mathrm{~mm}$ in thickness or one vug a few millimeters in diameter or for minerals replacing relict phases in a single thin section are considered together to approximate the equilibrium compositions. However, the mineral associations in veins that show texturally multistage mineral formation are omitted.

On the basis of the procedure for the definition of the mineral assemblages described in the preceding, the secondary mineral assemblages observed in the altered basalts recovered from Hole 504B during ODP Leg 111 can be classified into the following seven types in terms of the model basaltic system: (1) amphibole, (2) prehnite + zeolite, (3) prehnite + amphibole, (4) amphibole + zeolite, (5) prehnite + amphibole + zeolite, (6) epidote + prehnite + zeolite, and (7) amphibole + prehnite 


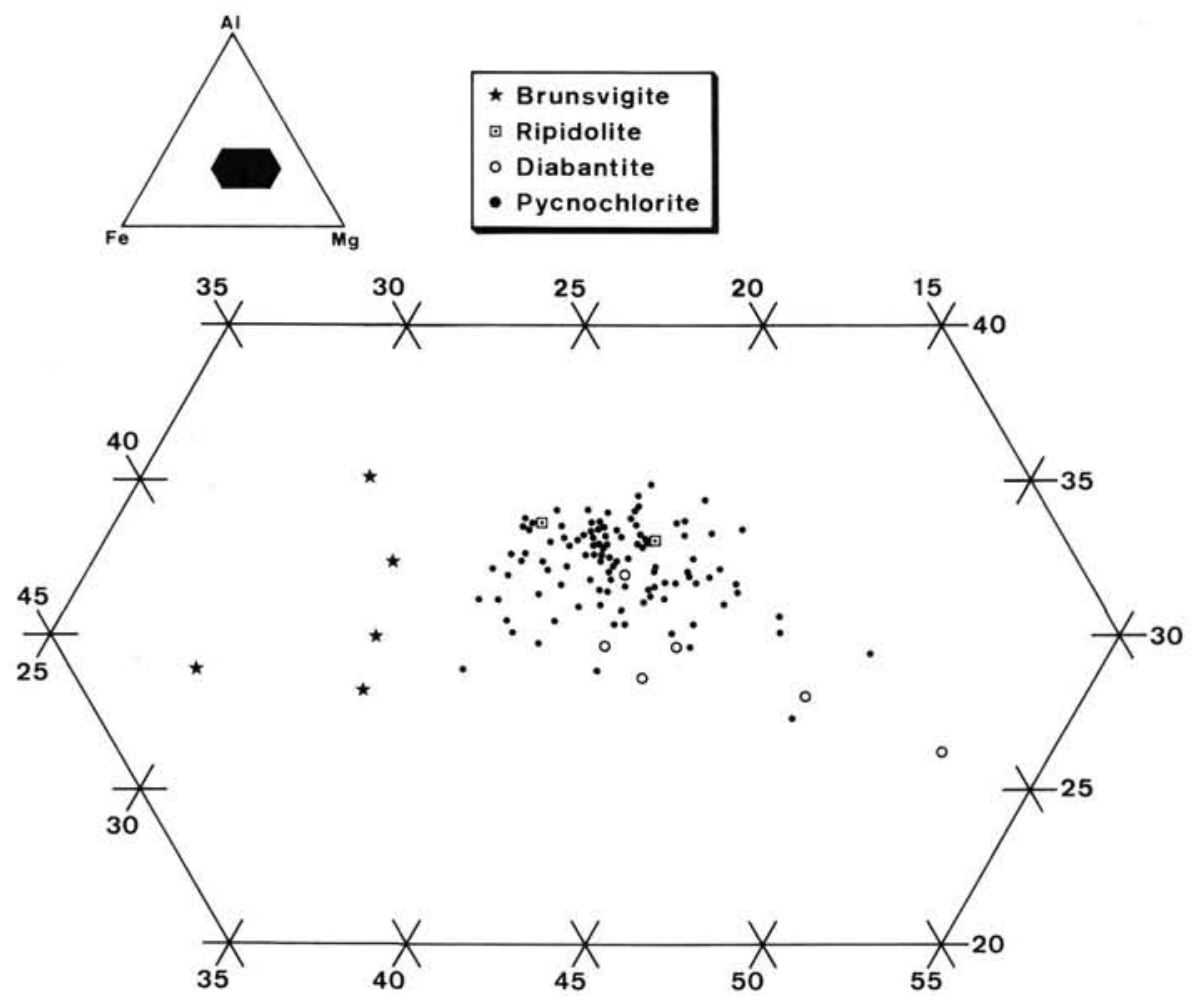

Figure 4. Compositional variation of $\mathrm{Al}-\mathrm{Fe}-\mathrm{Mg}$ for chlorite.

Table 6. Representative epidote analyses, Hole 504B, ODP Leg 111.

\begin{tabular}{llllllllll}
\hline $\begin{array}{l}\text { Core, section, } \\
\text { interval (cm) }\end{array}$ & $\begin{array}{c}\text { Depth } \\
\text { (mbsf) }\end{array}$ & $\mathrm{SiO}_{2}$ & $\mathrm{Al}_{2} \mathrm{O}_{3}$ & $\mathrm{Fe}_{2} \mathrm{O}_{3} * \mathrm{a}$ & $\mathrm{MnO}$ & $\mathrm{MgO}$ & $\mathrm{CaO}$ & $\mathrm{Total}$ & $\frac{\mathrm{Fe}^{3+}}{\left(\mathrm{Fe}^{3+}+\mathrm{Al}\right)}$ \\
\hline $142 \mathrm{R}-1,118-121$ & 1354.0 & 38.12 & 22.72 & 12.23 & 0.07 & 0.08 & 23.57 & 96.79 & 0.26 \\
& & 37.91 & 22.79 & 13.12 & 0.08 & 0.06 & 23.50 & 97.46 & 0.27 \\
$158 \mathrm{R}-1,32-34$ & 1482.8 & 38.22 & 26.22 & 9.35 & 0.10 & 0.03 & 23.77 & 97.69 & 0.19 \\
$158 \mathrm{R}-1,30-34$ & 1482.8 & 38.40 & 26.99 & 8.20 & 0.08 & 0.03 & 23.89 & 97.59 & 0.16 \\
& & 37.27 & 23.71 & 9.74 & 0.02 & 1.96 & 22.12 & 94.82 & 0.21 \\
& & 36.60 & 23.29 & 8.56 & 0.08 & 1.96 & 22.04 & 92.53 & 0.19 \\
\hline
\end{tabular}

a Total iron as $\mathrm{Fe}_{2} \mathrm{O}_{3}$.

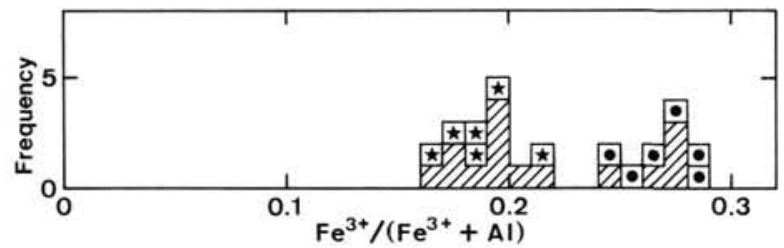

Figure 5. Frequency distribution of the $\mathrm{Fe}^{3+} /\left(\mathrm{Fe}^{3+}+\mathrm{Al}\right)$ ratio for epidotes. Dots and stars represent analyses of epidotes coexisting with prehnite and laumontite and with prehnite and actinolite, respectively.

+ epidote, all including chlorite, albite and/or oligoclase, quartz, and sphene. Of these, the amphibole-zeolite association may represent a disequilibrium assemblage as described previously. Thus, the low-variance (three-phase) mineral assemblages such as types (6) and (7), which were rarely observed in the examined rocks (Table 1), must be important for consideration of mineral paragenesis. Compositionally, the amphibole and zeolite in these two types of the mineral assemblages are actinolite and laumontite, respectively.
The mineral parageneses of types (6) and (7) assemblages are depicted in the AFC projections of Figures $10 \mathrm{C}$ and 10D, respectively. Besides the presence or absence of laumontite and actinolite, consideration of the $\mathrm{Al}-\mathrm{Fe}^{3+}$ substitution of prehnite and epidote finds that the epidote-prehnite tie-line shifts toward the $\mathrm{Al}-\mathrm{Ca}$ line from type (6) to type (7) assemblages.

The mineral paragenesis of Figure $10 \mathrm{C}$ is characterized by the mineral assemblage laumontite-prehnite-epidote (+ chlorite, + albite and/or oligoclase, + quartz, + sphene). This is one of the diagnostic mineral assemblages of the zeolite facies (e.g., Cho et al., 1986; Liou et al., 1987), described in the Onikobe geothermal system of northeast Japan (Liou et al., 1985b). This low-variance mineral assemblage indicates that the reaction laumontite + prehnite $=$ epidote + quartz + fluid does not occur perfectly; this reaction generally defines the upper stability of the zeolite facies (Cho et al., 1986). It is, therefore, most likely that the mineral paragenesis of Figure $10 \mathrm{C}$ represents the higher grade part of the zeolite facies. The mineral assemblage of type (2) may represent a partial mineral assemblage of the higher grade part of the zeolite facies. 
Table 7. Representative metamorphic plagioclase analyses, Hole 504B, ODP Leg 111.

\begin{tabular}{|c|c|c|c|c|c|c|c|c|c|c|}
\hline \multirow{2}{*}{$\begin{array}{l}\text { Core, section, } \\
\text { interval }(\mathrm{cm})\end{array}$} & \multirow{2}{*}{$\begin{array}{l}\text { Depth } \\
\text { (mbsf) }\end{array}$} & \multirow[b]{2}{*}{$\mathrm{SiO}_{2}$} & \multirow[b]{2}{*}{$\mathrm{Al}_{2} \mathrm{O}_{3}$} & \multirow[b]{2}{*}{$\mathrm{Fe}_{2} \mathrm{O}_{3}{ }^{\mathrm{a}}$} & \multirow[b]{2}{*}{$\mathrm{MgO}$} & \multirow[b]{2}{*}{$\mathrm{CaO}$} & \multirow[b]{2}{*}{$\mathrm{Na}_{2} \mathrm{O}$} & \multirow[b]{2}{*}{$\mathrm{K}_{2} \mathrm{O}$} & \multirow[b]{2}{*}{ Total } & $100 \mathrm{Ca}$ \\
\hline & & & & & & & & & & $\overline{(\mathrm{Ca}+\mathrm{Na})}$ \\
\hline \multirow[t]{2}{*}{$142 \mathrm{R}-1,118-121$} & 1354.0 & 64.63 & 23.51 & 0.02 & 0.00 & 5.02 & 7.09 & 0.00 & 100.27 & 28.12 \\
\hline & & 67.10 & 21.38 & 0.04 & 0.00 & 0.90 & 11.46 & 0.03 & 100.91 & 4.16 \\
\hline $142 \mathrm{R}-2,73-75$ & 1355.0 & 64.09 & 22.27 & 0.30 & 0.05 & 2.74 & 9.64 & 0.02 & 99.11 & 13.57 \\
\hline \multirow[t]{2}{*}{$149 \mathrm{R}-2,50-53$} & 1418.9 & 66.70 & 20.87 & 0.16 & 0.01 & 0.68 & 11.73 & 0.05 & 100.20 & 3.10 \\
\hline & & 63.00 & 23.75 & 0.23 & 0.03 & 4.07 & 9.52 & 0.01 & 99.61 & 19.11 \\
\hline $152 \mathrm{R}-1,5-8$ & 1436.0 & 66.44 & 19.17 & 0.31 & 0.00 & 0.62 & 11.47 & 0.00 & 98.01 & 2.90 \\
\hline \multirow[t]{2}{*}{$152 \mathrm{R}-1,17-19$} & 1436.1 & 66.52 & 20.87 & 0.17 & 0.00 & 1.36 & 10.44 & 0.02 & 99.38 & 6.72 \\
\hline & & 67.13 & 21.35 & 0.01 & 0.02 & 1.28 & 10.95 & 0.02 & 100.76 & 6.07 \\
\hline \multirow[t]{2}{*}{$152 \mathrm{R}-1,61-64$} & 1436.5 & 67.16 & 21.01 & 0.16 & 0.01 & 0.86 & 11.52 & 0.05 & 100.77 & 3.96 \\
\hline & & 67.18 & 20.59 & 0.06 & 0.00 & 0.64 & 11.41 & 0.01 & 99.89 & 3.01 \\
\hline \multirow[t]{2}{*}{ 153R-1, 77-79 } & 1446.1 & 66.82 & 21.27 & 0.05 & 0.03 & 0.74 & 11.47 & 0.02 & 100.40 & 3.44 \\
\hline & & 67.20 & 20.36 & 0.24 & 0.00 & 0.53 & 11.72 & 0.00 & 100.05 & 2.44 \\
\hline 156R-1, 37-39 & 1464.2 & 66.20 & 21.37 & 0.07 & 0.06 & 2.12 & 9.79 & 0.02 & 99.63 & 10.69 \\
\hline \multirow[t]{3}{*}{$157 \mathrm{R}-1,1-6$} & 1473.1 & 62.80 & 23.76 & 0.18 & 0.03 & 3.81 & 8.96 & 0.05 & 99.59 & 19.03 \\
\hline & & 66.58 & 21.49 & 0.07 & 0.01 & 0.90 & 11.14 & 0.01 & 100.20 & 4.27 \\
\hline & & 64.27 & 22.74 & 0.12 & 0.06 & 2.27 & 10.53 & 0.03 & 100.02 & 10.64 \\
\hline \multirow[t]{4}{*}{$157 \mathrm{R}-1,60-63$} & 1473.7 & 67.22 & 20.90 & 0.20 & 0.05 & 0.83 & 11.43 & 0.00 & 100.63 & 3.86 \\
\hline & & 68.97 & 20.15 & 0.10 & 0.00 & 0.46 & 11.02 & 0.00 & 100.70 & 2.25 \\
\hline & & 67.71 & 20.64 & 0.02 & 0.00 & 0.57 & 11.56 & 0.06 & 100.56 & 2.65 \\
\hline & & 66.43 & 20.22 & 0.32 & 0.03 & 1.18 & 10.80 & 0.03 & 99.01 & 5.69 \\
\hline $158 \mathrm{R}-1,16-18$ & 1482.7 & 65.46 & 20.80 & 0.21 & 0.00 & 1.83 & 10.80 & 0.00 & 99.10 & 8.56 \\
\hline \multirow[t]{2}{*}{$158 \mathrm{R}-1,18-20$} & 1482.7 & 65.44 & 22.65 & 0.11 & 0.00 & 2.38 & 10.40 & 0.00 & 100.98 & 11.23 \\
\hline & & 64.12 & 23.45 & 0.27 & 0.02 & 2.82 & 10.18 & 0.00 & 100.86 & 13.28 \\
\hline \multirow[t]{3}{*}{$158 \mathrm{R}-1,30-34$} & 1482.8 & 62.16 & 24.04 & 0.10 & 0.01 & 4.29 & 9.66 & 0.05 & 100.31 & 19.71 \\
\hline & & 66.93 & 21.15 & 0.00 & 0.01 & 0.86 & 11.05 & 0.01 & 100.01 & 4.12 \\
\hline & & 68.35 & 19.83 & 0.30 & 0.03 & 0.64 & 11.35 & 0.02 & 100.52 & 3.02 \\
\hline $164 \mathrm{R}-1,55-58$ & 1515.7 & 65.88 & 22.10 & 0.00 & 0.03 & 1.71 & 10.76 & 0.02 & 100.50 & 8.07 \\
\hline
\end{tabular}

a Total iron as $\mathrm{Fe}_{2} \mathrm{O}_{3}$.

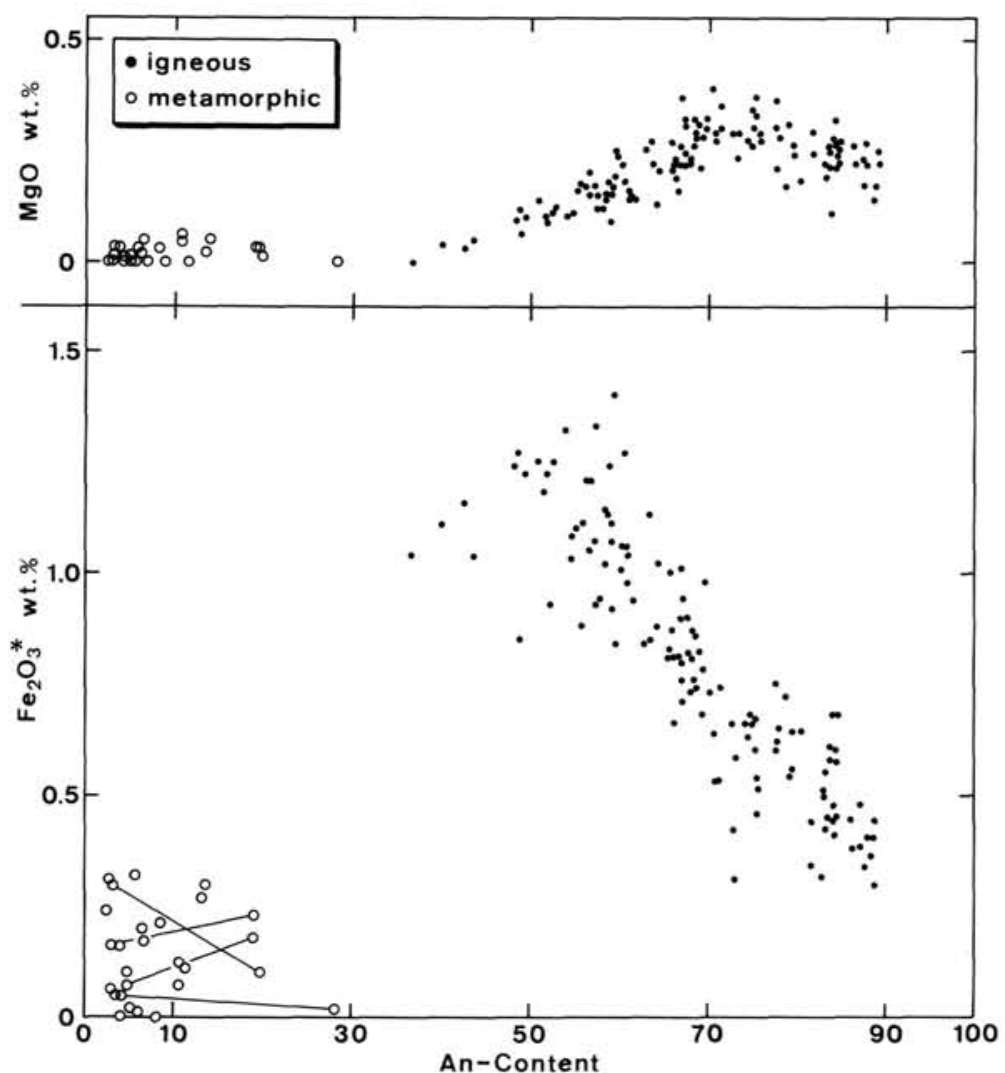

Figure 6. Variations of $\mathrm{MgO}$ and $\mathrm{Fe}_{2} \mathrm{O}_{3}{ }^{*}$ contents against An content for primary (igneous) and metamorphic plagioclases. The tie-lines represent a coexisting albite and oligoclase pair. 
Table 8. Representative amphibole analyses, Hole 504B, ODP Leg 111.

\begin{tabular}{|c|c|c|c|c|c|c|c|c|c|c|c|c|}
\hline $\begin{array}{l}\text { Core, section, } \\
\text { interval }(\mathrm{cm})\end{array}$ & $\begin{array}{l}\text { Depth } \\
\text { (mbsf) }\end{array}$ & $\mathrm{SiO}_{2}$ & $\mathrm{TiO}_{2}$ & $\mathrm{Al}_{2} \mathrm{O}_{3}$ & $\mathrm{FeO}^{\mathrm{a}}$ & $\mathrm{MnO}$ & $\mathrm{MgO}$ & $\mathrm{CaO}$ & $\mathrm{Na}_{2} \mathrm{O}$ & $\mathrm{K}_{2} \mathrm{O}$ & $\mathrm{Cl}$ & Total \\
\hline \multicolumn{13}{|l|}{ Anthophyllite } \\
\hline $169 \mathrm{R}-1,28-31$ & 1547.9 & 57.48 & 0.00 & 0.30 & 9.67 & 0.10 & 28.40 & 0.28 & 0.02 & 0.00 & nd & 96.25 \\
\hline \multicolumn{13}{|l|}{ Cummingtonite } \\
\hline $143 \mathrm{R}-1,108-112$ & 1360.4 & 47.84 & 0.30 & 7.33 & 18.35 & 0.26 & 19.85 & 1.03 & 0.53 & 0.01 & nd & 95.50 \\
\hline $144 \mathrm{R}-1,43-47$ & 1369.1 & 56.52 & 0.00 & 1.32 & 14.16 & 0.12 & 24.69 & 0.38 & 0.11 & 0.00 & nd & 97.30 \\
\hline $145 \mathrm{R}-3,137-138$ & 1384.2 & 56.08 & 0.05 & 1.94 & 11.57 & 0.10 & 26.52 & 1.16 & 0.17 & 0.00 & nd & 97.59 \\
\hline $169 \mathrm{R}-1,28-31$ & 1547.9 & 55.78 & 0.00 & 0.78 & 15.06 & 0.16 & 24.02 & 0.51 & 0.13 & 0.00 & nd & 96.44 \\
\hline \multicolumn{13}{|c|}{ Actinolitic Ca-amphibole with $\mathrm{Si}>7.25$ and $(\mathrm{Ca}+\mathrm{Na}) \mathrm{B}>1.34$} \\
\hline \multirow[t]{2}{*}{$142 \mathrm{R}-1,2-4$} & 1352.8 & 53.07 & 0.52 & 2.89 & 14.18 & 0.23 & 15.40 & 10.30 & 0.37 & 0.10 & nd & 97.06 \\
\hline & & 49.93 & 0.21 & 4.35 & 16.75 & 0.38 & 15.56 & 8.19 & 0.32 & 0.03 & nd & 95.72 \\
\hline $142 \mathrm{R}-1,118-121$ & 1354.0 & 50.88 & 0.26 & 3.77 & 18.75 & 0.34 & 11.74 & 10.93 & 0.37 & 0.01 & nd & 97.05 \\
\hline \multirow[t]{2}{*}{$142 \mathrm{R}-2,73-75$} & 1355.0 & 51.45 & 0.24 & 3.90 & 19.18 & 0.23 & 10.91 & 11.60 & 0.34 & 0.00 & nd & 97.85 \\
\hline & & 48.18 & 0.06 & 5.70 & 19.31 & 0.50 & 12.77 & 8.11 & 0.41 & 0.00 & nd & 95.04 \\
\hline $143 \mathrm{R}-1,108-112$ & 1360.4 & 50.65 & 0.06 & 5.35 & 14.76 & 0.29 & 14.36 & 8.68 & 0.49 & 0.05 & nd & 94.69 \\
\hline $144 \mathrm{R}-1,43-47$ & 1369.1 & 50.51 & 0.05 & 4.49 & 15.80 & 0.37 & 14.43 & 10.06 & 0.49 & 0.02 & nd & 96.22 \\
\hline $145 \mathrm{R}-3,137-138$ & 1384.2 & 52.69 & 0.27 & 2.70 & 14.60 & 0.24 & 15.58 & 11.46 & 0.41 & 0.04 & nd & 97.99 \\
\hline \multirow[t]{2}{*}{$147 \mathrm{R}-2,30-33$} & 1399.2 & 52.83 & 0.08 & 2.06 & 18.34 & 0.30 & 12.68 & 12.21 & 0.22 & 0.00 & nd & 98.72 \\
\hline & & 50.54 & 0.44 & 2.57 & 27.60 & 0.61 & 9.16 & 7.31 & 0.68 & 0.08 & nd & 98.99 \\
\hline \multirow[t]{2}{*}{$149 \mathrm{R}-2,50-53$} & 1418.9 & 52.04 & 0.11 & 2.23 & 14.76 & 0.28 & 14.87 & 12.51 & 0.46 & 0.01 & nd & 97.27 \\
\hline & & 53.85 & 0.38 & 1.27 & 17.36 & 0.39 & 15.52 & 8.81 & 0.54 & 0.02 & nd & 98.14 \\
\hline \multirow[t]{4}{*}{$149 \mathrm{R}-2,57-59$} & 1419.0 & 49.69 & 0.35 & 4.18 & 18.26 & 0.32 & 12.27 & 9.94 & 1.18 & 0.00 & 0.17 & 96.36 \\
\hline & & 48.58 & 0.28 & 4.02 & 21.25 & 0.38 & 9.63 & 9.80 & 1.09 & 0.00 & 0.20 & 95.23 \\
\hline & & 52.53 & 0.33 & 1.74 & 15.62 & 0.24 & 14.62 & 10.48 & 0.44 & 0.00 & 0.06 & 96.06 \\
\hline & & 52.53 & 0.17 & 1.33 & 17.46 & 0.30 & 13.17 & 10.87 & 0.36 & 0.00 & 0.08 & 96.27 \\
\hline 150R-1, $81-83$ & 1427.2 & 51.64 & 0.18 & 2.48 & 16.66 & 0.24 & 12.05 & 12.47 & 0.22 & 0.00 & nd & 95.94 \\
\hline $152 \mathrm{R}-1,5-8$ & 1436.0 & 51.22 & 0.53 & 3.92 & 14.05 & 0.00 & 15.48 & 10.70 & 1.07 & 0.00 & 0.12 & 97.09 \\
\hline & & 49.67 & 0.42 & 4.26 & 16.22 & 0.29 & 13.11 & 10.45 & 0.88 & 0.00 & 0.09 & 95.39 \\
\hline $152 \mathrm{R}-1,17-19$ & 1436.1 & 51.43 & 0.72 & 5.23 & 13.05 & 0.24 & 15.81 & 10.57 & 0.91 & 0.03 & nd & 97.99 \\
\hline $152 \mathrm{R}-1,61-64$ & 1436.5 & 52.97 & 0.14 & 4.34 & 19.10 & 0.40 & 10.17 & 9.42 & 0.19 & 0.06 & nd & 96.79 \\
\hline $153 \mathrm{R}-1,77-79$ & 1446.1 & 50.76 & 0.20 & 3.54 & 19.08 & 0.31 & 11.31 & 11.05 & 0.28 & 0.03 & nd & 96.56 \\
\hline & & 50.85 & 0.31 & 1.88 & 26.90 & 0.35 & 8.79 & 7.68 & 0.43 & 0.08 & nd & 97.27 \\
\hline $154 \mathrm{R}-1,116-119$ & 1455.5 & 46.40 & 0.35 & 3.65 & 28.86 & 0.76 & 5.99 & 10.22 & 0.60 & 0.06 & nd & 96.89 \\
\hline & & 48.37 & 0.41 & 3.47 & 31.44 & 0.65 & 5.12 & 8.58 & 0.48 & 0.14 & nd & 98.66 \\
\hline 156R-1, 37-39 & 1464.2 & 51.18 & 0.31 & 1.97 & 22.14 & 0.77 & 9.08 & 12.08 & 0.23 & 0.00 & nd & 97.76 \\
\hline $157 \mathrm{R}-1,1-6$ & 1473.1 & 51.01 & 0.49 & 4.20 & 13.91 & 0.17 & 15.62 & 10.66 & 0.79 & 0.06 & nd & 96.91 \\
\hline & & 51.73 & 0.47 & 4.24 & 15.51 & 0.43 & 15.80 & 8.75 & 0.62 & 0.00 & nd & 97.55 \\
\hline $157 \mathrm{R}-1,2-5$ & 1473.1 & 52.79 & 0.15 & 1.79 & 12.82 & 0.25 & 16.02 & 10.99 & 0.49 & 0.00 & 0.08 & 95.38 \\
\hline & & 50.81 & 0.34 & 3.54 & 13.57 & 0.28 & 15.32 & 10.40 & 0.85 & 0.00 & 0.09 & 95.20 \\
\hline & & 49.78 & 0.51 & 4.24 & 14.54 & 0.23 & 14.52 & 10.37 & 0.85 & 0.00 & 0.11 & 95.15 \\
\hline $157 \mathrm{R}-1,60-63$ & 1473.7 & 53.03 & 0.11 & 1.33 & 21.78 & 0.59 & 9.87 & 11.79 & 0.12 & 0.02 & nd & 98.64 \\
\hline & & 51.47 & 0.26 & 3.58 & 18.20 & 0.33 & 13.24 & 8.64 & 0.49 & 0.00 & nd & 96.21 \\
\hline $158 \mathrm{R}-1,16-18$ & 1482.7 & 51.67 & 0.18 & 2.69 & 17.58 & 0.17 & 12.70 & 11.35 & 0.36 & 0.00 & 0.09 & 96.79 \\
\hline & & 51.44 & 0.36 & 3.48 & 15.12 & 0.17 & 14.23 & 10.44 & 0.46 & 0.00 & 0.06 & 95.76 \\
\hline $158 \mathrm{R}-1,18-20$ & 1482.7 & 51.59 & 0.66 & 4. & 16. & 0. & 13 & 1 & 0. & 0.02 & nd & 98.59 \\
\hline $158 \mathrm{R}-1,30-34$ & 1482.8 & 50.28 & 0.39 & 3.62 & 16.11 & 0.29 & 13.22 & 10.78 & 0.38 & 0.00 & nd & 95.07 \\
\hline & & 53.14 & 0.25 & 2.52 & 18.52 & 0.29 & 13.80 & 8.71 & 0.37 & 0.03 & nd & 97.63 \\
\hline $158 \mathrm{R}-1,32-34$ & 1482.8 & 51.86 & 0.16 & 4.92 & 15.72 & 0.22 & 15.53 & 8.24 & 0.88 & 0.00 & 0.09 & 97.62 \\
\hline $159 \mathrm{R}-1,27-29$ & 1488.4 & 52.77 & 0.16 & 3.14 & 15.03 & 0.28 & 13.90 & 11.71 & 0.41 & 0.01 & nd & 97.41 \\
\hline $159 \mathrm{R}-1,52-56$ & 1488.6 & 47.50 & 0.44 & 3.93 & 24.97 & 0.32 & 7.36 & 10.41 & 0.58 & 0.03 & nd & 95.54 \\
\hline & & 48.15 & 0.21 & 2.75 & 29.52 & 0.43 & 7.14 & 7.32 & 0.60 & 0.01 & nd & 96.13 \\
\hline $160 \mathrm{R}-1,25-27$ & 1495.0 & 51.21 & 0.61 & 2.68 & 15.31 & 0.00 & 13.69 & 11.40 & 0.52 & 0.07 & nd & 95.49 \\
\hline & & 48.17 & 0.35 & 3.67 & 27.85 & 0.56 & 7.46 & 7.46 & 0.44 & 0.03 & nd & 95.99 \\
\hline $160 \mathrm{R}-1,59-60$ & 1495.3 & 51.55 & 0.50 & 3.56 & 17.85 & 0.24 & 13.31 & 10.13 & 0.59 & 0.02 & nd & 97.75 \\
\hline $164 \mathrm{R}-1,55-58$ & 1515.7 & 51.99 & 0.55 & 3.17 & 17.31 & 0.33 & 13.35 & 10.62 & 0.39 & 0.02 & nd & 97.73 \\
\hline & & 49.73 & 0.76 & 5.07 & 14.90 & 0.29 & 15.82 & 8.72 & 0.89 & 0.05 & nd & 96.23 \\
\hline $165 \mathrm{R}-1,72-76$ & 1530.2 & 48.68 & 0.63 & 3.79 & 23.76 & 0.09 & 8.29 & 9.38 & 0.54 & 0.16 & nd & 95.32 \\
\hline & & 49.22 & 0.42 & 3.01 & 27.09 & 0.22 & 8.41 & 7.72 & 0.50 & 0.13 & nd & 96.72 \\
\hline $169 \mathrm{R}-1,28-31$ & 1547.9 & 50.98 & 0.75 & 4.73 & 15.33 & 0.25 & 16.38 & 8.99 & 0.69 & 0.01 & nd & 98.11 \\
\hline $170 \mathrm{R}-1,49-53$ & 1554.1 & 50.45 & 0.27 & 4.14 & 18.12 & 0.29 & 12.14 & 10.94 & 0.44 & 0.02 & nd & 96.81 \\
\hline & & 53.16 & 0.20 & 2.05 & 15.34 & 0.37 & 15.64 & 9.22 & 0.35 & 0.01 & nd & 96.34 \\
\hline olnoto $\mathrm{Co}$ & & 7 & ( & $N$ & .34 & & & & & & & \\
\hline $142 \mathrm{R}-1,2-4$ & 1352.8 & 53.09 & 0.33 & 3.02 & 18. & 0.30 & 14 & 7.43 & 0.27 & 0.03 & nd & 97.47 \\
\hline $142 R-2,73-75$ & 1355.0 & 52.32 & 0.12 & 4.47 & 20.38 & 0.53 & 14.22 & 5.58 & 0.43 & 0.02 & nd & 98.07 \\
\hline $144 \mathrm{R}-1,43-47$ & 1369.1 & 51.93 & 0.06 & 5.14 & 17.25 & 0.31 & 17.69 & 5.02 & 0.43 & 0.01 & nd & 97.84 \\
\hline $147 \mathrm{R}-2,30-33$ & 1399.2 & 49.69 & 0.24 & 2.46 & 29.82 & 0.75 & 8.50 & 4.48 & 0.37 & 0.03 & nd & 96.34 \\
\hline $153 \mathrm{R}-1,77-79$ & 1446.1 & 47.56 & 0.33 & 4.64 & 28.66 & 0.37 & 8.08 & 7.17 & 0.46 & 0.12 & nd & 97.39 \\
\hline $158 \mathrm{R}-1,32-34$ & 1482.8 & 50.72 & 0.06 & 3.92 & 19.20 & 0.26 & 13.87 & 7.08 & 0.48 & 0.00 & 0.09 & 95.68 \\
\hline $160 \mathrm{R}-1,59-60$ & 1495.3 & 50.79 & 0.39 & 1.93 & 23.22 & 0.45 & 11.99 & 7.52 & 0.28 & 0.00 & nd & 96.57 \\
\hline $165 \mathrm{R}-1,72-76$ & 1530.2 & 51.39 & 0.22 & 3.17 & 21.57 & 0.46 & 13.99 & 5.27 & 0.36 & 0.00 & nd & 96.43 \\
\hline
\end{tabular}


Table 8 (continued).

\begin{tabular}{|c|c|c|c|c|c|c|c|c|c|c|c|c|}
\hline $\begin{array}{l}\text { Core, section, } \\
\text { interval }(\mathrm{cm})\end{array}$ & $\begin{array}{l}\text { Depth } \\
\text { (mbsf) }\end{array}$ & $\mathrm{SiO}_{2}$ & $\mathrm{TiO}_{2}$ & $\mathrm{Al}_{2} \mathrm{O}_{3}$ & $\mathrm{FeO}^{\mathrm{a}}$ & $\mathrm{MnO}$ & $\mathrm{MgO}$ & $\mathrm{CaO}$ & $\mathrm{Na}_{2} \mathrm{O}$ & $\mathrm{K}_{2} \mathrm{O}$ & $\mathrm{Cl}$ & Total \\
\hline \multicolumn{13}{|c|}{ Hornblendic Ca-amphibole with $\mathrm{Si}<7.25$ and $(\mathrm{Ca}+\mathrm{Na}) \mathrm{B}>1.34$} \\
\hline \multirow[t]{2}{*}{$142 \mathrm{R}-1,118-121$} & \multirow[t]{2}{*}{1354.0} & 44.29 & 3.21 & 9.52 & 11.55 & 0.24 & 14.69 & 9.76 & 3.87 & 0.06 & nd & 97.19 \\
\hline & & 41.90 & 0.13 & 14.29 & 16.83 & 0.37 & 13.77 & 8.52 & 1.76 & 0.02 & nd & 97.59 \\
\hline \multirow[t]{2}{*}{ 145R-3, 137-138 } & \multirow[t]{2}{*}{1384.2} & 42.34 & 1.43 & 17.95 & 14.24 & 0.38 & 8.73 & 10.77 & 2.26 & 0.08 & nd & 98.18 \\
\hline & & 45.76 & 1.00 & 7.87 & 16.64 & 0.17 & 15.42 & 9.82 & 1.32 & 0.08 & nd & 98.08 \\
\hline $152 \mathrm{R}-1,5-8$ & 1436.0 & 47.06 & 0.73 & 7.87 & 11.38 & 0.13 & 15.38 & 10.73 & 1.87 & 0.13 & 0.13 & 95.41 \\
\hline $152 \mathrm{R}-1,17-19$ & 1436.1 & 48.47 & 0.63 & 8.86 & 11.74 & 0.20 & 15.63 & 10.97 & 1.4 & 0.03 & nd & 97.99 \\
\hline $159 \mathrm{R}-1,52-56$ & 1488.6 & 42.3 & 0.91 & 9.03 & 28.18 & 0.49 & 5.54 & 7.16 & 2. & 0.05 & nd & 95.74 \\
\hline $163 \mathrm{R}-1,135-138$ & 1513.0 & 45.26 & 1.52 & 10.37 & 13.21 & 0.10 & 14.24 & 10.36 & 2.41 & 0.03 & nd & 97.50 \\
\hline $164 \mathrm{R}-1,55-58$ & 1515.7 & 46.94 & 0.94 & 6.93 & 13.66 & 0.28 & 15.60 & 10.16 & 1.10 & 0.05 & nd & 95.66 \\
\hline $169 \mathrm{R}-1,28-31$ & 1547.9 & 44.15 & 1.81 & 13.24 & 11.50 & 0.12 & 12.96 & 11.18 & 1.78 & 0.13 & nd & 96.87 \\
\hline $170 \mathrm{R}-1,49-53$ & 1554.1 & 44.26 & 0.07 & 13.25 & 15.05 & 0.18 & 13.21 & 8.62 & 1.92 & 0.00 & nd & 96.56 \\
\hline \multicolumn{13}{|c|}{ Hornblendic Ca-amphibole with $\mathrm{Si}<7.25$ and $(\mathrm{Ca}+\mathrm{Na}) \mathrm{B}<1.34$} \\
\hline $142 \mathrm{R}-1,2-4$ & 1352.8 & 45.61 & 0.18 & 9.03 & 17.90 & 0.22 & 17.83 & 5.89 & 0.25 & 0.04 & nd & 96.95 \\
\hline $144 \mathrm{R}-1,43-47$ & 1369.1 & 49.00 & 0.38 & 6.33 & 18.38 & 0.35 & 16.86 & 7.09 & 0.20 & 0.00 & nd & 98.59 \\
\hline $156 \mathrm{R}-1,37-39$ & 1464.2 & 47.34 & 0.22 & 7.93 & 20.10 & 0.28 & 12.83 & 7.84 & 0.17 & 0.01 & nd & 96.72 \\
\hline
\end{tabular}

Note: nd $=$ not determined. $\mathrm{Si}, \mathrm{Ca}$, and $\mathrm{Na}$ were calculated on the basis of $\mathrm{O}=23$.

a Total iron as $\mathrm{FeO}$.

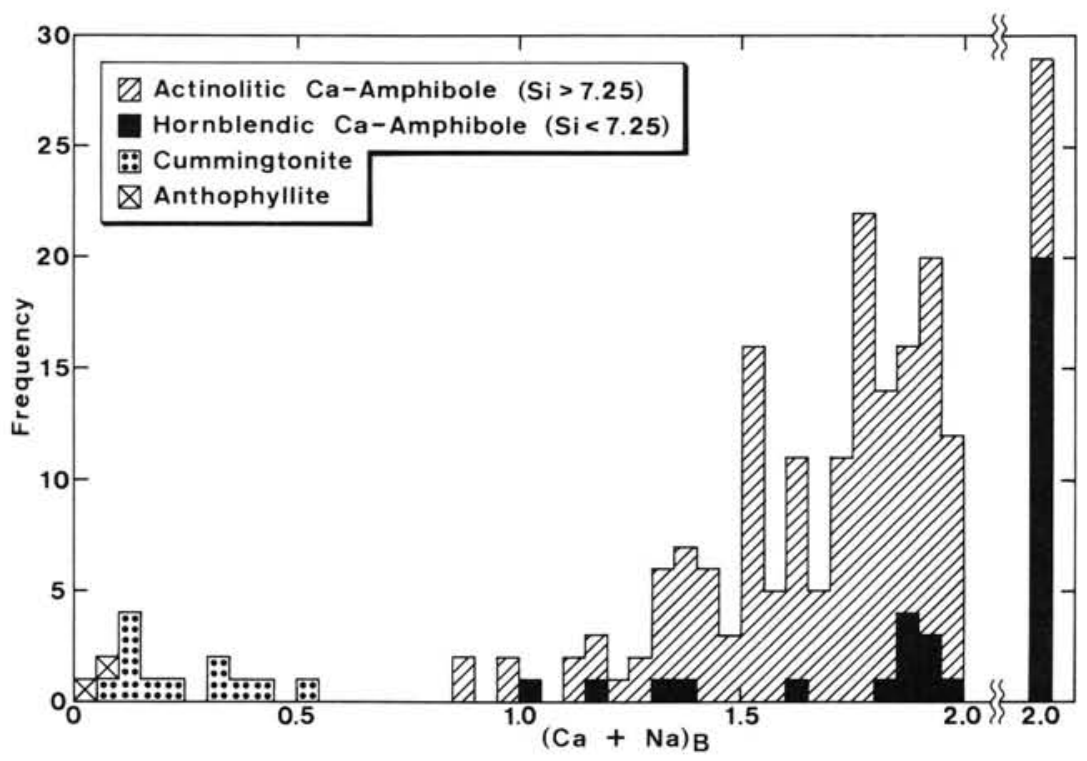

Figure 7. Frequency distribution of $(\mathrm{Ca}+\mathrm{Na}) \mathrm{B}$ values for amphibole.

The mineral paragenesis of Figure 10D, which is characterized by the mineral assemblage of prehnite-actinolite-epidote (+ chlorite, + albite and/or oligoclase, + quartz, + sphene), has been generally assumed to belong to the greenschist facies. However, the recent experimental study of a model basaltic system by Liou et al. (1985a) showed that the critical mineral assemblage of Figure 10D (prehnite-actinolite-epidote) can be seen to occupy a large pressure-temperature field transitional from the zeolite or prehnite-pumpellyite to greenschist facies at low pressures. In the literature, the mineral assemblage of Figure $10 \mathrm{D}$ has been reported from low-pressure-type metamorphic terrains such as the Tanzawa Mountains (Seki et al., 1969; Arai, 1987), Karmutsen volcanics (Kuniyoshi and Liou, 1976), Del Puerto ophiolite (Evarts and Schiffman, 1983), and Horokanai ophiolite (Ishizuka, 1985). From these facts, Liou et al. (1985a) proposed the prehnite-actinolite facies to describe this assemblage. In this study, this facies is adopted to denote the mineral assemblage of Figure 10D, although there are some uncertainties about the reactions defining the transition from zeolite to the prehnite-actinolite facies, especially about the zeolite-out and actinolite-in reactions. The type (3) mineral assemblage may be a partial mineral assemblage of the prehnite-actinolite facies.

Previous studies on the alteration of Hole 504B showed that the mineral facies of the sheeted dike complex reached the greenschist facies (Alt et al., 1985, 1986). The present study reveals that prehnite is a common secondary mineral coexisting with actinolite, chlorite, and/or epidote, indicating that the temperature did not reach the reaction leading to the disappearance of prehnite, for example, prehnite + chlorite + quartz = clinozoisite + tremolite + fluid; this reaction defines the upper stability of the prehnite-actinolite facies. It follows that the mineral facies attained even in the deepest level of Hole 504B reached the prehnite-actinolite facies and not the greenschist facies in the sense of Liou et al. (1985a). 


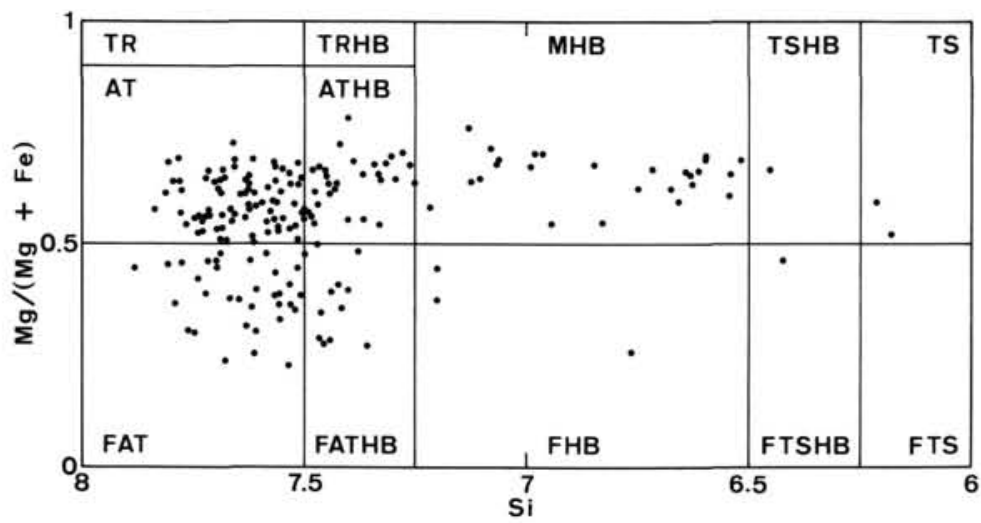

Figure 8. Variation of $\mathrm{Si}$ content against the $\mathrm{Mg} /(\mathrm{Mg}+\mathrm{Fe})$ ratio for $\mathrm{Ca}$ amphiboles with $(\mathrm{Ca}+\mathrm{Na}) \mathrm{B}>1.34$. $\mathrm{TR}=$ tremolite; $\mathrm{AT}=$ actinolite; $\mathrm{FAT}=$ ferroactinolite; $\mathrm{TRHB}=$ tremolitic hornblende; $\mathrm{ATHB}=$ actinolitic hornblende; FATHB = ferroactinolitic hornblende; $\mathrm{MHB}=$ magnesiohornblende; $\mathrm{FHB}=$ ferrohornblende; TSHB $=$ tschermakitic hornblende; FTSHB = ferrotschermakitic hornblende; $\mathrm{TS}=$ tschermakite; and FTS $=$ ferrotschermakite.

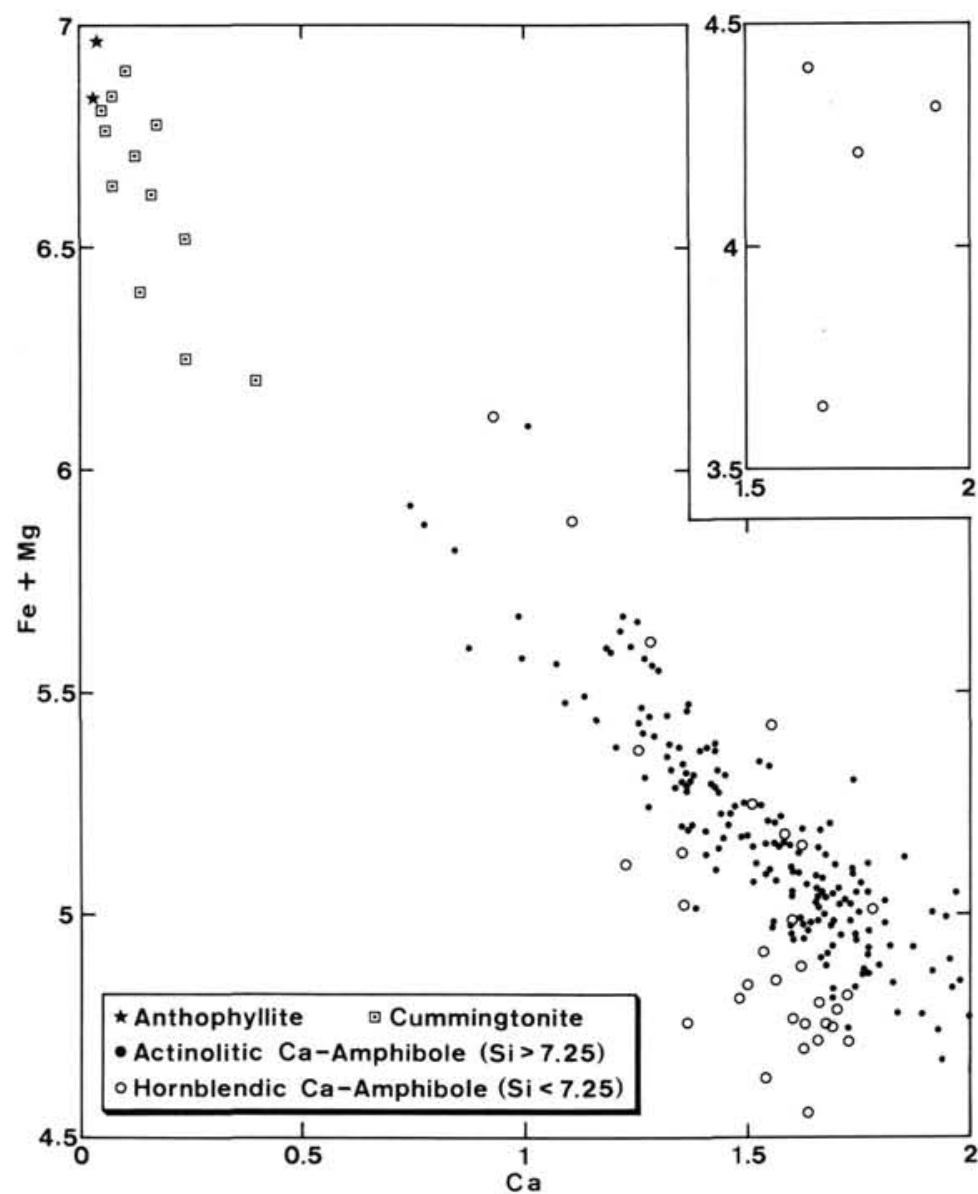

Figure 9. Variation of $\mathrm{Ca}$ content against $(\mathrm{Mg}+\mathrm{Fe})$ values for amphibole.

\section{CONCLUSIONS}

Alteration of the basalts recovered from Hole 504B during ODP Leg 111 is characterized by (1) lack of evidence for strong shear stress and widespread penetrative deformation, and, hence, good preservation of the primary (igneous) structures and textures; (2) partial to total replacement of primary olivine, plagio- clase, and clinopyroxene by secondary minerals and the extensive to incipient development of secondary minerals in veins, fractures, vugs, or breccia matrix; and (3) the occurrence of the low-variance mineral assemblages laumontite + prehnite + epidote and prehnite + actinolite + epidote, both of which include chlorite, albite and/or oligoclase, quartz, and sphene. The mineral paragenesis described in terms of the model basal- 
Table 9. Representative analyses of sodic augite, sphene, talc, anhydrite, pyrite, chalcopyrite, and Fe-Ti oxide, Hole 504B, ODP Leg 111.

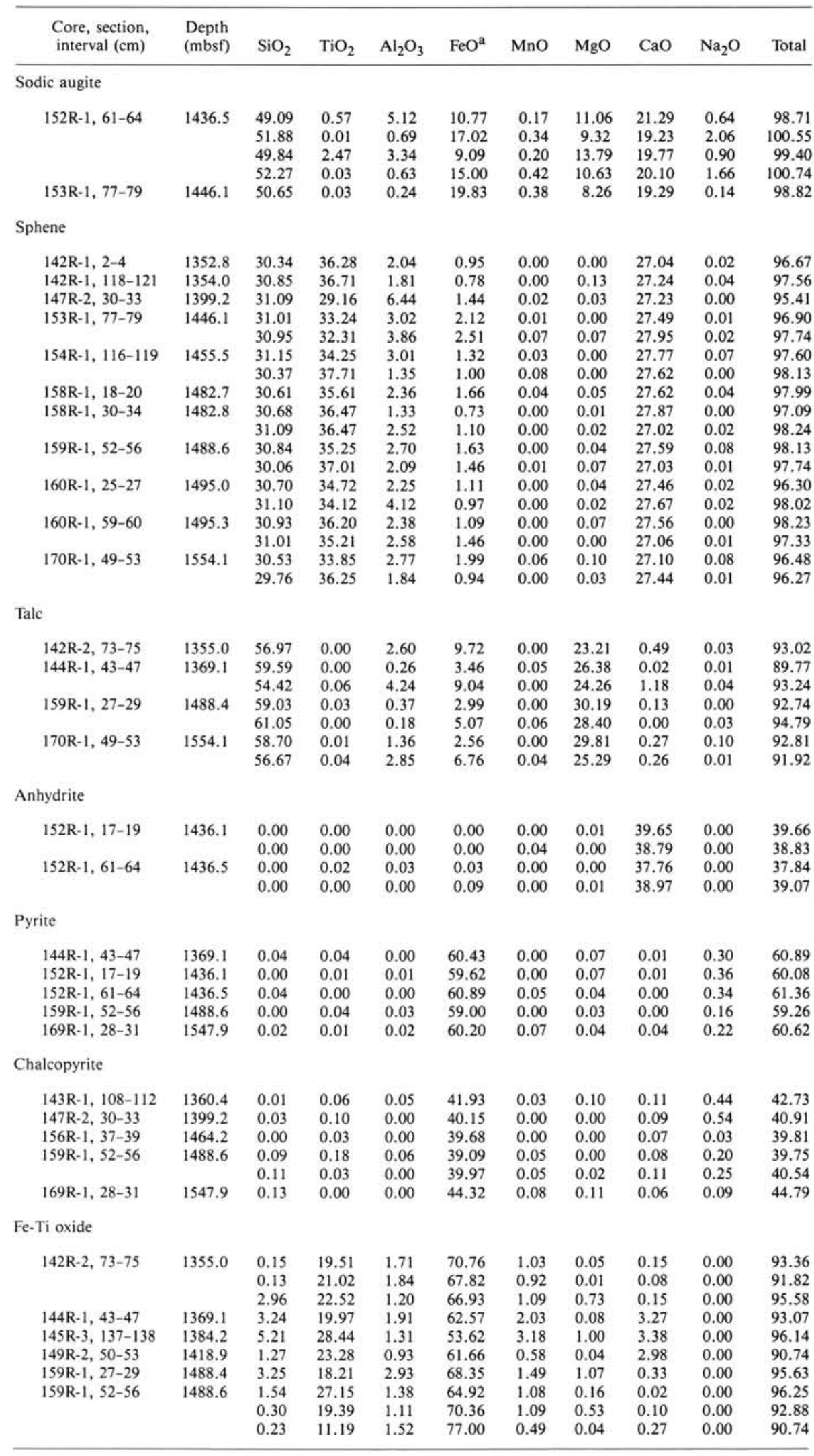

a Total iron as FeO. 

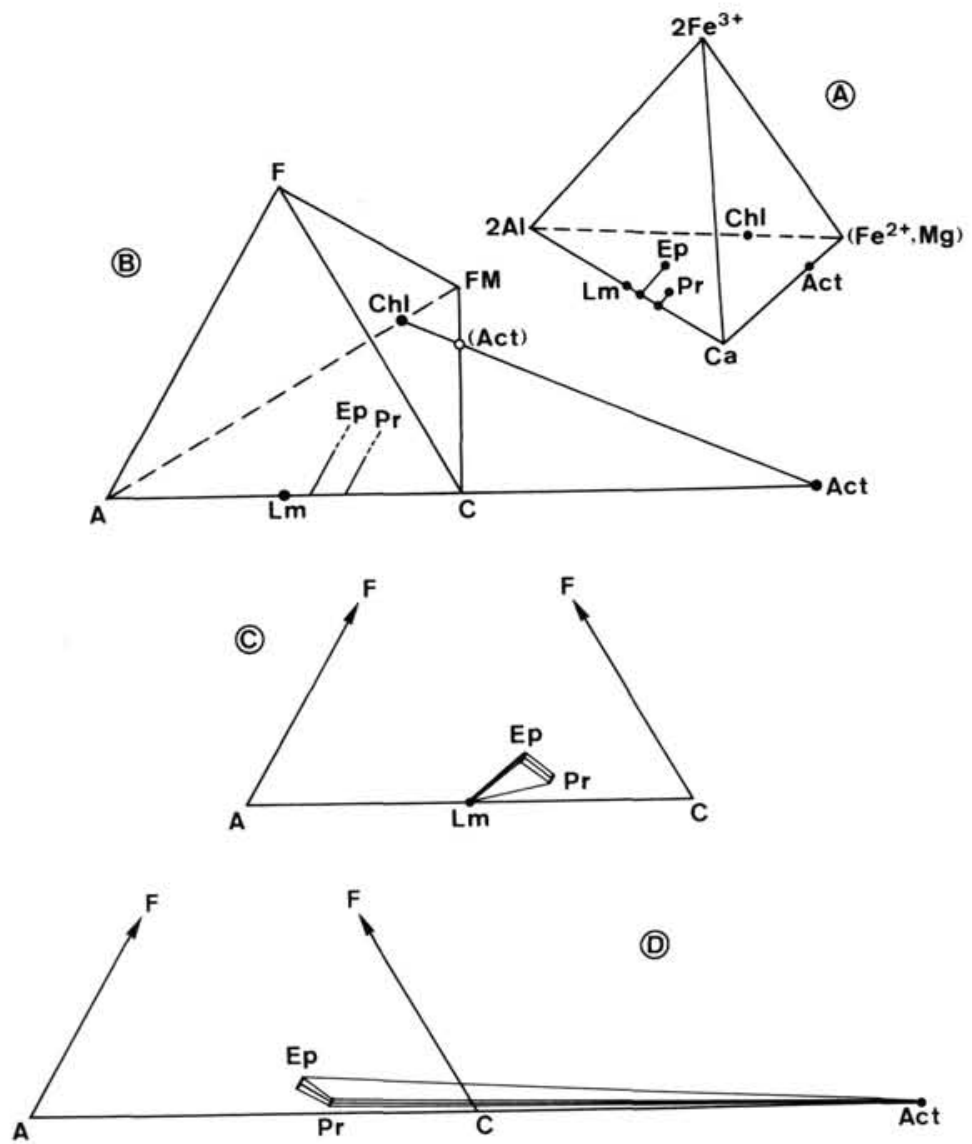

Figure 10. A. Compositions of actinolite, laumontite, epidote, prehnite, and chlorite in the tetrahedron $2 \mathrm{Al}-2 \mathrm{Fe}^{3+}-\left(\mathrm{Fe}^{2+}, \mathrm{Mg}\right)-\mathrm{Ca}$. B. Projection of these phases from chlorite composition onto an $\mathrm{A}(2 \mathrm{Al})-\mathrm{F}\left(2 \mathrm{Fe}^{3+}\right)-\mathrm{C}(\mathrm{Ca})$ diagram. $\mathbf{C}$ and $\mathbf{D}$. Mineral parageneses and compositional variations for type (6) and (7) mineral assemblages in the AFC projections, respectively. $\mathrm{Lm}=$ laumontite; $\mathrm{Ep}=$ epidote; $\mathrm{Pr}=$ prehnite $\mathrm{Chl}=$ chlorite $;$ and $\mathrm{Act}=$ actinolite .

tic system reveals that the basalts underwent zeolite facies to prehnite-actinolite facies alteration. In a strict sense, the mineral assemblage of the greenschist facies is not found in the samples examined here, suggesting that the temperatures of the greenschist facies $\left(350^{\circ}-400^{\circ} \mathrm{C}\right.$ inferred from fig. 4 of Liou et al., 1985a) were not attained in the deepest portion of Hole 504B.

\section{ACKNOWLEDGMENTS}

I am indebted to Dr. Y. Kojima (National Institute of Polar Research, Japan) and Prof. S. Banno (Kyoto University) for providing me facilities for microprobe analyses. This work was supported in part by funds from the Cooperation Program (No. 88131/Ishizuka) provided by Ocean Research Institute, University of Tokyo, and in part by Grant-inAid for Scientific Research from Ministry of Education of Japan (No. 63740471/Ishizuka).

\section{REFERENCES}

Alt, J. C., Honnorez, J., Laverne, C., and Emmermann, R., 1986. Hydrothermal alteration of a $1 \mathrm{~km}$ section through the upper oceanic crust, Deep Sea Drilling Project Hole 504B: mineralogy, chemistry and evolution of basalt-seawater interactions. J. Geophys. Res., 91: $10,309-10,335$.

Alt, J. C., Laverne, C., and Muehlenbachs, K., 1985. Alteration of the upper oceanic crust: mineralogy and processes in Deep Sea Drilling Project Hole 504B, Leg 83. In Anderson, R. N., Honnorez, J., Becker, K., et al., Init. Repts. DSDP, 83: Washington (U.S. Govt. Printing Office), 217-247.
Arai, T., 1987. Tectonics of Tanzawa Mountains-constraints from metamorphic petrology. Chishitsugaku Zasshi, 93:185-200.

Aumento, F., Lancarevic, B. C., and Ross, K. I., 1971. Hudson geotraverse: geology of the Mid-Atlantic Ridge at $45^{\circ} \mathrm{N}$. Philos. Trans. $R$. Soc. London, $A, 268: 623-650$.

Bonatti, E. H., Honnorez, J., Kirst, P., and Radicati, F., 1975. Metagabbros from the Mid-Atlantic Ridge at $06^{\circ} \mathrm{N}$ : contact-hydrothermal-dynamic metamorphism beneath the axial valley. J. Geol., 83: 61-78.

Cann, J. R., 1969. Spilites from the Carlsberg Ridge, Indian Ocean. J. Petrol., 10:1-19.

Cann, J. R., and Funnell, B. M., 1967. Palmer Ridge: a section through the upper part of the oceanic crust. Nature, 213:661-664.

Cho, M., and Liou, J. G., 1987. Prehnite-pumpellyite to greenschist facies transition in the Karmutsen metabasites, Vancouver Island, B.C. J. Petrol., 28:417-443.

Cho, M., Liou, J. G., and Maruyama, S., 1986. Transition from the zeolite to prehnite-pumpellyite facies in the Karmutsen metabasites, Vancouver Island, British Columbia. J. Petrol., 27:467-494.

Evarts, R. C., and Schiffman, P., 1983. Submarine hydrothermal metamorphism of the Del Puerto ophiolite, California. Am. J. Sci., 283: 289-340.

Helmstaedt, H., 1977. Postmagmatic textures and fabrics of gabbros and peridotites from DSDP Site 334. In Aumento, F., Melson, W. G., et al., Init. Repts. DSDP, 37: Washington (U.S. Govt. Printing Office), 757-762.

Hey, M. H., 1954. A new review of the chlorites. Mineral. Mag., 30: 277-297. 
Honnorez, J., Mevel, C., and Montigny, R., 1984. Geotectonic significance of gneissic amphibolites from the Vema Fracture Zone, equatorial Mid-Atlantic Ridge. J. Geophys. Res., 89:11,379-11,400.

Ishizuka, H., 1985. Prograde metamorphism of the Horokanai ophiolite in the Kamuikotan zone, Hokkaido, Japan. J. Petrol., 26:391417.

Ito, E., and Anderson, A. T., Jr., 1983. Submarine metamorphism of gabbros from the Mid-Cayman Rise: petrographic and mineralogic constraints on hydrothermal processes at slow-spreading ridges. Contrib. Mineral. Petrol., 82:371-388.

Kuniyoshi, S., and Liou, J. G., 1976. Contact metamorphism of the Karmutsen Volcanics, Vancouver Island, British Columbia. J. Petrol., 17:73-99.

Laverne, C., 1983. Occurrence of melanite and aegirine-augite in Deep Sea Drilling Project Hole 504B. In Cann, J. R., Langseth, M. G., Honnorez, J., Von Herzen, R. P., White, S. M., et al., Init. Repts. DSDP, 69: Washington (U.S. Govt. Printing Office), 593-605.

Leake, B. E., 1978. Nomenclature of amphiboles. Am. Mineral., 63: 1023-1052.

Liou, J. G., Maruyama, S., and Cho, M., 1985a. Phase equilibria and mineral parageneses of metabasites in low-grade metamorphism. Mineral. Mag., 49:321-333.

1987. Very low-grade metamorphism of volcanic and volcaniclastic rocks-mineral assemblages and mineral facies. In Frey, M., Very Low-Grade Metamorphism: New York (Blackie and Son), 59113.

Liou, J. G., Seki, Y., Guillemette, R. N., and Sakai, H., 1985b. Compositions and parageneses of secondary minerals in the Onikobe geothermal system, Japan. Chem. Geol., 49:1-20.

Matthews, D. H., Vine, F. J., and Cann, J. R., 1965. Geology of an area of the Carlsberg Ridge, Indian Ocean. Geol. Soc. Am. Bull., $76: 675-682$.
Melson, W. G., and van Andel, T. H., 1966. Metamorphism in the MidAtlantic Ridge, $22^{\circ} \mathrm{N}$ latitude. Mar. Geol., 4:165-186.

Miyashiro, A., Shido, F., and Ewing, M., 1971. Metamorphism in the Mid-Atlantic Ridge near $24^{\circ}$ and $34^{\circ} \mathrm{N}$. Philos. Trans. R. Soc. London, A, 268:589-603.

Ploshko, V. V., Bogdanov, Y. A., and Kuyazeva, D. N., 1970. Gabbroamphibolite from the abyssal Romanche trench, Atlantic region. Dokl. Akad. Nauk SSSR, 192:40-43.

Robinson, P., Spear, F. S., Schumacher, J. C., Laird, J., Klein, C., Evans, B. W., and Doolan, B. L., 1982. Phase relations of metamorphic amphiboles: natural occurrence and theory. In Veblen, D. R., and Ribbe, P. H. (Eds.), Amphiboles: Petrology and Experimental Phase Relations: Rev. Mineral., 9B:1-227.

Seki, Y., Oki, Y., Matsuda, T., Mikami, K., and Okumura, K., 1969. Metamorphism in the Tanzawa Mountains, central Japan. J. Jpn. Assoc. Min. Petrol. Econ. Geol., 66:1-24, 49-75.

Shipboard Scientific Party, 1988. Site 504: Costa Rica Rift. In Becker, K., Sakai, H., et al., Proc. ODP, Init. Repts., 111: College Station, TX (Ocean Drilling Program), 35-251.

Vanko, D. A., 1986. High-chlorine amphiboles from oceanic rocks: product of highly-saline hydrothermal fluids? Am. Mineral., 71:5159.

Zen, E., 1974. Prehnite- and pumpellyite-bearing assemblages, west side of the Appalachian metamorphic belt, Pennsylvania to Newfoundland. J. Petrol., 15:197-242.

Date of initial receipt: 17 August 1988

Date of acceptance: 2 March 1989

Ms 111B-121 